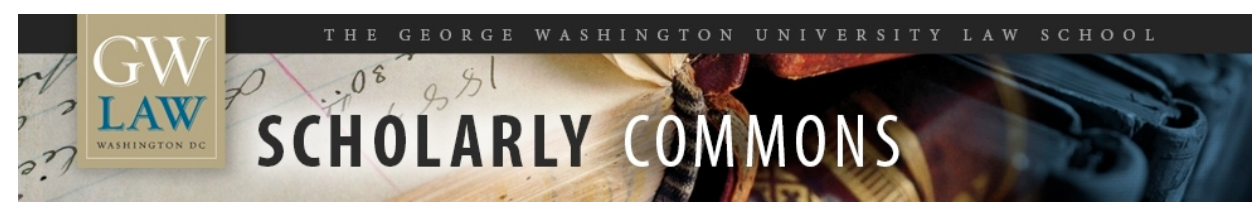

GW Law Faculty Publications \& Other Works

Faculty Scholarship

2019

\title{
Grading Trump's China Trade Strategy
}

Steve Charnovitz

George Washington University Law School, scharnovitz@law.gwu.edu

Follow this and additional works at: https://scholarship.law.gwu.edu/faculty_publications

Part of the Law Commons

\section{Recommended Citation}

Charnovitz, Steve, Grading Trump's China Trade Strategy (2019). GWU Law School Public Law Research Paper No. 2019-26; GWU Legal Studies Research Paper No. 2019-26. Available at SSRN:

https://ssrn.com/abstract=3393083

This Article is brought to you for free and open access by the Faculty Scholarship at Scholarly Commons. It has been accepted for inclusion in GW Law Faculty Publications \& Other Works by an authorized administrator of Scholarly Commons. For more information, please contact spagel@law.gwu.edu. 


\title{
Grading Trump's China Trade Strategy
}

\author{
Steve Charnovitz*
}

\section{Content}

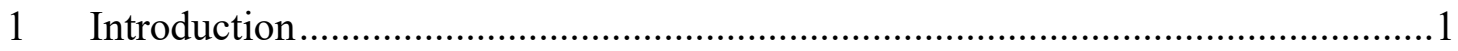

2 Overview of US Complaints About China .......................................................

3 Detailed Examination of US Complaints............................................................

3.1 Analytical Methodology ........................................................................

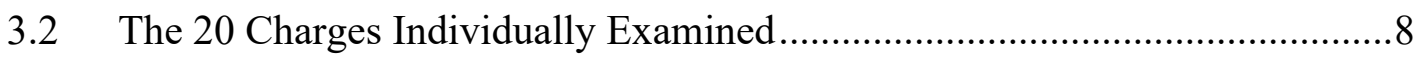

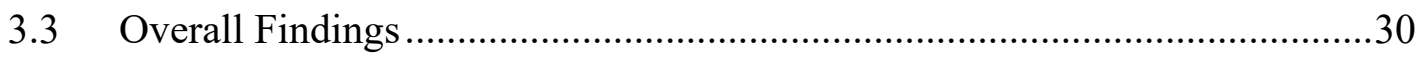

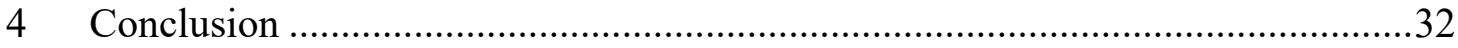

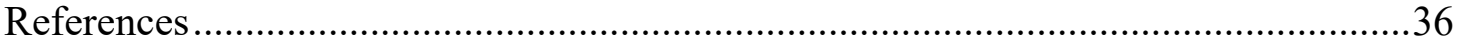

\begin{abstract}
Although much has been written about the ongoing trade war between China and the United States from 2017 to early 2019, this literature omits detailed examination of the substance of the US trade complaints about China. This article seeks to fill that gap in the literature by unpacking the 20 most prominent complaints that are being levelled by the Trump Administration. The article finds that half of the complaints involve behaviour that is contrary to WTO rules and yet the Trump Administration has lodged only three WTO cases against that behaviour. The Trump Administration justifies this omission on the ground that WTO dispute settlement is not capable of resolving legal complaints against China's nonmarket economy and that many of the Chinese measures characterized in this article as WTO-illegal are actually permitted by the WTO. The article suggests that the real reason why the Administration chose not to bring multiple new WTO cases against China is that the Administration prefers to confront China with power-based measures in the form of unilateral tariffs. Moreover, robust WTO dispute settlement is viewed by the Trump Administration as unwanted international control over disguised trade protectionism long favoured by US trade officials.
\end{abstract}

\section{Introduction}

United States (US) President Donald J. Trump and his Administration have made China their top trade target. ${ }^{1}$ Pronouncing US trade with China to be unfair, Trump Administration

*Prof. Steve Charnovitz, George Washington University, USA. Forthcoming, European Yearbook of International Economic Law 2019. This article is current as of 19 April 2019 and sources from the internet were accessed on this date.

${ }^{1}$ To be sure, Trump's fixation on China's economic policies is misplaced as the US has greater interests in securing from China more accommodating policies on regional security and climate change. Cooperation with China is especially vital on climate change to address classic market and government failures. 
officials in July 2018 began imposing a 25\% tariff on \$50 billion of imports from China pursuant to the statutory authority in Section 301 of the Trade Act of $1974 .^{2}$ The Section 301 authority provides for negotiations with the target country, ${ }^{3}$ and in December 2018, the Administration announced a pause in raising tariffs pending new talks with China. ${ }^{4}$ As of mid-April 2019, these China-US negotiations are ongoing, but President Trump has revealed that even if a trade deal with China is achieved, the US tariffs may stay in place for a "substantial period of time." 5

The Trump Administration justified the original Section 301 actions as an attack on four types of behaviour by the Chinese government: (1) forced technology transfer in China, (2) involuntary licensing requirements in China, (3) technology acquisitions by China in the United States, and (4) cyber and intellectual property theft by China in the United States. ${ }^{6}$ After China retaliated against the first tranche of Section 301 tariffs, the Administration, in September 2018, imposed 10\% tariffs on \$200 billion worth of imports from China. ${ }^{7}$

Besides China, President Trump has hurled criticism at several additional trade targets including the North American Free Trade Agreement (NAFTA), the Trans-Pacific Partnership (TPP), the World Trade Organization (WTO), and the European Union (EU). The competition for pride of place after China has stayed tight, but, as I see it, the Administration's second biggest trade target is the WTO Appellate Body. ${ }^{8}$ Trump's Office of the US Trade Representative (USTR) relentlessly attacks the Appellate Body:

For many years, the WTO Appellate Body repeatedly seized more power for itself - while undermining and disregarding the very rules under which the dispute system was created. ${ }^{9}$

The Appellate Body's approach "fails to apply the WTO rules as written and agreed to by the United States and other WTO Members." ${ }^{10}$

The "WTO Appellate Body has repeatedly sought to create new obligations not covered in WTO Agreements." ${ }^{11}$

[E]fforts by the Appellate Body to create new obligations are not legitimate. ${ }^{12}$

We will not allow the WTO Appellate Body and dispute settlement system to force the United States into a straitjacket of obligations to which we never agreed. ${ }^{13}$

219 USC $\S 2415(a)(1)$.

${ }^{3} 19$ USC $\$ 2465(\mathrm{a})$.

${ }^{4}$ USTR, 2019 Trade Policy Agenda and 2018 Annual Report, March 2019, p. 21. Prior to the pause, the Administration had threatened to raise the tariff levels and to impose tariffs on more imports from China.

${ }^{5}$ Davis B, Ballhaus R, Trump says tariffs on Chinese goods will stay on for 'substantial period of time'. Wall Street Journal, 21 March 2019.

${ }^{6}$ USTR, Notice of Determination of Action Pursuant to Section 301, 83 F.R. 14907, 6 April 2018. See Nos. $1,6,18$ and 20 below. Navarro P, Trump's tariffs are a defense against China's aggression. Wall Street Journal, 21 June 2018, p. A17.

${ }^{7}$ USTR, 2019 Trade Policy Agenda and 2018 Annual Report, March 2019, p. 20

${ }^{8}$ Nixon S, Trump puts the WTO on the ropes. Wall Street Journal, 11 July 2018. The Appellate Body serves as the WTO's appellate tribunal.

${ }^{9}$ USTR, 2019 Trade Policy Agenda and 2018 Annual Report, March 2019, p. 6.

${ }^{10}$ USTR, 2019 Trade Policy Agenda and 2018 Annual Report, March 2019, p. 26.

${ }^{11}$ USTR, 2019 Trade Policy Agenda and 2018 Annual Report, March 2019, p. 26.

${ }^{12}$ USTR, 2019 Trade Policy Agenda and 2018 Annual Report, March 2019, p. 26.

${ }^{13}$ USTR, 2019 Trade Policy Agenda and 2018 Annual Report, March 2019, p. 27. 
In my view, all of these complaints lack validity. Even worse is USTR's absurd complaint that "judicial activism" by the Appellate Body is an "important reason for the failure of the multilateral negotiations" at the WTO. ${ }^{14}$ USTR also objects to the Appellate Body's longtime rule allowing an appellator hearing an appeal to continue doing so even if her term expires during the appeal. Abandoning this rule would delay many Appellate Body proceedings, and so there is no small contradiction in the fact that USTR also objects to tardy Appellate Body rulings.

The Trump Administration's twin criticisms of China and the Appellate Body feed off each other. To wit:

The Appellate Body's "activism had the disastrous effect of making it harder for marketbased countries like the United States to push back against unfair trade practices abroad [...]."15

We will resist efforts by China - or any other country - to hide behind international bureaucracies in an effort to hinder the ability of the United States to take robust actions, when necessary, in response to unfair practices abroad. ${ }^{16}$

China and other WTO Members have put forth proposals that endorse changing the rules of WTO dispute settlement to accommodate and authorize the very WTO Appellate Body actions that the United States has protested. ${ }^{17}$

Instead of constraining market distorting countries like China, the WTO has in some cases given them an unfair advantage over the United States and other market based economies. ${ }^{18}$

Although the United States can readily utilize Section 301 tariffs to sanction China, Section 301 cannot be utilized to sanction the Appellate Body. Instead, USTR has sought to put the WTO appellate court out of business by objecting to the replacement of Appellate Body members when their judicial terms expire. Currently, four of the seven seats on the Appellate Body are vacant as a result of the refusal of the US representative to the WTO Dispute Settlement Body (DSB) to join the consensus needed to commence the appointment process.

Both forms of the Trump Administration's economic aggression are inconsistent with WTO rules. The Section 301 tariffs against China violate Articles I and II of the WTO's General Agreement on Tariffs and Trade (GATT). The refusal by the United States to appoint new judges is inconsistent with the procedural requirement in Article 17.2 of the WTO Dispute Settlement Understanding (DSU) that "Vacancies shall be filled as they arise."19

These twin USTR assaults undermine prosperity and the rule of law. The reciprocal trade sanctions between China and the US will reduce economic growth in both economies. The

\footnotetext{
${ }^{14}$ USTR, 2019 Trade Policy Agenda and 2018 Annual Report, March 2019, p. 6.

${ }^{15}$ USTR, 2019 Trade Policy Agenda and 2018 Annual Report, March 2019, p. 6.

${ }^{16}$ USTR, 2018 Trade Policy Agenda and 2017 Annual Report, March 2018, p. 4.

${ }^{17}$ USTR, 2019 Trade Policy Agenda and 2018 Annual Report, March 2019, p. 27.

${ }^{18}$ USTR, 2018 Trade Policy Agenda and 2017 Annual Report, March 2018, p. 2.

19 Petersmann (2018), p. 187.
} 
US tariff actions are protectionist in practice ${ }^{20}$ by inhibiting imports in the short run and by realigning production and supply chains in the long-run (that are a wellspring of China's economic clout). The disruption of the Appellate Body has hindered the ability of countries to secure WTO decisions in a timely fashion so to induce other countries to adhere to their WTO obligations. For the same reasons, these dual assaults can harm the economic interests of the rest of the world, particularly those countries that regularly use WTO dispute settlement. On the other hand, the supply chain disruptions can also shift investment and production from China to third-country beneficiaries.

In parallel to the Trump Administration's trade complaints about China, the Administration has criticized the Paris climate accord for being an "unfair" agreement that would favour China over the United States. In announcing that he would withdraw the US from the Paris Agreement, Trump alleged that the climate accord would allow China to increase its emissions for 13 years even though the United States could not. ${ }^{21}$ Back in 2012, Trump had famously declared that "the concept of global warming was created by and for the Chinese in order to make U.S. manufacturing non-competitive." 22

For climate, trade, and many other fields, US unilateralism is not just a means, but rather is a central part of the Administration's conception of a good world order. As Adam Tooze has noted, "As far as the American trade hawks are concerned, competition within an agreed international order is to be welcomed only so long as the competitors agree to play by America's rules, both economic and geopolitical."23 Likewise USTR: " The United States will not allow the WTO - or any other multilateral organization - to prevent us from taking actions that are essential to the economic well-being of the American people."24

\section{Overview of US Complaints About China}

Although the Trump Administration has not produced a white paper detailing exactly what it considers China to be doing wrong on trade, one can stitch together a bill of complaint from various statements by President Trump, the White House, USTR, and other parts of the Trump Administration. ${ }^{25}$ China is accused of numerous examples of "unfair" trade practices and "economic aggression" against the United States. ${ }^{26}$ Precisely what renders the named practices "unfair" goes unexplained.

\footnotetext{
${ }^{20}$ USTR denies that the Trump Administration is engaging in protectionism. Lighthizer, at APEC, says defending U.S. market against unfair trade is not protectionism. World Trade Online, 21 May 2017.

${ }^{21}$ White House, Statement by President Trump on the Paris Climate Accord, 1 June 2017.

22 https://twitter.com/realdonaldtrump/status/265895292191248385?lang=en

23 Tooze A, Is this the end of the American century? London Review of Books 41(7), 4 April 2019, https://www.lrb.co.uk/v41/n07/adam-tooze/is-this-the-end-of-the-american-century

${ }^{24}$ USTR, 2018 Trade Policy Agenda and 2017 Annual Report, March 2018, p. 2.

${ }^{25}$ For a US private sector analysis, see Business Roundtable, Recommendations for Chinese reforms to address trade and investment barriers, July 2018, https://s3.amazonaws.com/brt.org/archive/letters/BRT\%20China\%20Priorities.pdf

${ }^{26}$ White House, What You Need to Know About President Donald J. Trump's Actions Responding to China's Unfair Trade Practices, 6 April 2018; White House, Remarks by President Trump at Signing of a Presidential Memorandum Targeting China's Economic Aggression, 22 March 2018; White House, Statement by the President Regarding Trade with China, 15 June 2018.
} 
Trump's grievances against China are manifold, but for the purposes of this article can summarized in the following 20 charges: ${ }^{27}$

1. The government of China "is forcing United States companies to transfer technology to Chinese counterparts." 28 "Beijing now requires many American businesses to hand over their trade secrets as the cost of doing business in China."29

2. "Chinese industrial policy" seeks to "capture industries of the future" through several means such as public investment and export restraints on critical raw materials. ${ }^{30}$ "China's unfair industrial policies, like the 'Made in China 2025' policy initiative, clearly state China's goal of taking away domestic and international market share from foreigners." 31 "Too often, China flouts the rules to achieve industrial policy objectives." 32

3. China imposes "discriminatory non-tariff barriers." ${ }^{33}$ China protects its home market with "high tariffs, non-tariff barriers, and other regulatory hurdles." 34

4. "China has banned imports of United States agricultural products such as poultry."35

5. China uses "market-distorting forces, including subsidies and state-owned enterprises" to promote "excess capacity" and "overproduction of steel and aluminium". ${ }^{36}$

6. China requires US companies to license intellectual property "at less than economic value." ${ }^{37}$

7. "China disregards many of its WTO's transparency obligations [...]."38

8. "China has been a particularly bad actor when it comes to trade remedies."39

9. "China is increasingly attempting to force foreign enterprises to localize valuable data or information within China [...]."40

\footnotetext{
${ }^{27}$ If the list were going over 20 , this study would have included currency manipulation and weak enforcement of US intellectual property rights.

${ }^{28}$ White House, Statement from the President, 17 September 2018.

${ }^{29}$ White House, Remarks by Vice President Pence to the Hudson Institute on the Administration's Policy Toward China, 4 October 2018.

${ }^{30}$ White House, Office of Trade and Manufacturing Policy, How China's economic aggression threatens the technology and intellectual property of the United States and the world, June 2018, pp. 2, 16.

${ }^{31}$ White House, What You Need to Know About President Donald J. Trump's Actions Responding to China's Unfair Trade Practices, 6 April 2018.

${ }^{32}$ USTR, 2018 USTR Report to Congress on China's WTO compliance, February 2019, p. 8.

${ }^{33}$ White House, President Donald J. Trump is Confronting China's Unfair Trade Policies, 29 May 2018.

${ }^{34}$ White House, Office of Trade and Manufacturing Policy, How China's economic aggression threatens the technology and intellectual property of the United States and the world, June 2018, p. 1.

${ }^{35}$ White House, President Donald J. Trump is Confronting China's Unfair Trade Policies, 29 May 2018.

${ }^{36}$ White House, President Donald J. Trump is Confronting China's Unfair Trade Policies, 29 May 2018; White House, Statement of the United States Regarding China Talks, 31 January 2019.

${ }^{37}$ White House, President Donald J. Trump is Confronting China's Unfair Trade Policies, 29 May 2018.

${ }^{38}$ USTR, 2018 USTR Report to Congress on China's WTO compliance, February 2019, p. 9.

${ }^{39}$ USTR, 2018 USTR Report to Congress on China's WTO compliance, February 2019, p. 8.

${ }^{40}$ White House, Office of Trade and Manufacturing Policy, How China's economic aggression threatens the technology and intellectual property of the United States and the world, June 2018, p. 8.
} 
10. China imposes "unfair retaliation" against the Trump Administration's Section 301 tariffs. ${ }^{41}$ China's retaliation against the Trump Administration's Section 232 steel and aluminium tariffs "appears to be inconsistent with China's [WTO] obligations $[\ldots] . " 42$

11. China continues to follow a "state-led, mercantilist approach to the economy and trade, despite WTO members' expectations - and China's own representations - that China would transform its economy and pursue the open, market-oriented policies endorsed by the WTO."43 "WTO membership comes with expectations that an acceding member not only will strictly adhere to WTO rules, but also will support open, market-oriented policies," and "China has failed to comply with these expectations." 44

12. China exhibits the largest trade "deficit of any country in the history of our world"45 and the "trade relationship between the United States and China must be much more equitable." 46 "I have great respect and affection for my friend President Xi, but I have made clear that our trade imbalance is just not acceptable." 47

13. "The United States will request that tariffs and taxes between the two countries [China and US] be reciprocal in nature and value."48 "China imposes much higher tariffs on United States exports than the United States imposes on China. ${ }^{49}$ "If they charge us, we charge them the same thing. That's the way it's got to be."50

14. Projects in China's Belt and Road Initiative "generally ignore market principles and fail to adhere to internationally accepted best practices in financing, infrastructure development and government procurement." 51

15. China "has already achieved a leading position in many traditional manufacturing industries" through several methods including "lax and weakly enforced environmental and health and safety standards." 52

${ }^{41}$ White House, Statement from President Donald J. Trump on Additional Proposed Section 301 Remedies, 5 April 2018.

${ }^{42}$ WTO, China - Additional Duties on Certain Products from the United States, Request for Establishment of a WTO Panel by the United States, WT/DS558/2, 19 October 2018.

${ }^{43}$ USTR, 2018 USTR Report to Congress on China's WTO compliance, February 2019, p. 2.

${ }^{44}$ USTR, 2018 USTR Report to Congress on China's WTO compliance, February 2019, p.3.

${ }^{45}$ White House, Remarks by President Trump at Signing of a Presidential Memorandum Targeting China's Economic Aggression, 22 March 2018.

${ }^{46}$ White House, Statement from the President Regarding Trade with China, 18 June 2018.

${ }^{47}$ White House, Remarks by President Trump to the 73rd Session of the United Nations General Assembly, New York, 25 September 2018.

${ }^{48}$ White House, Statement on Steps to Protect Domestic Technology and Intellectual Property from China's Discriminatory and Burdensome Trade Practices, 29 May 2018.

${ }^{49}$ White House, President Donald J. Trump is Confronting China's Unfair Trade Policies, 29 May 2018.

${ }^{50}$ White House, Remarks by President Trump at Signing of a Presidential Memorandum Targeting China's Economic Aggression, 22 March 2018.

${ }^{51}$ USTR, 2018 USTR Report to Congress on China's WTO compliance, February 2019, p. 15.

${ }^{52}$ White House, Office of Trade and Manufacturing Policy, How China's economic aggression threatens the technology and intellectual property of the United States and the world, June 2018, p. 1. 
16. China uses a "predatory 'debt trap' model" to "secure and control core global resources globally."53

17. "China's policies are contributing to a dramatic misallocation of global resources that leaves everyone - including the Chinese people - poorer than they would be in a world of more efficient markets." 54

18. "China directs and unfairly facilitates the systematic investment in, and acquisition of, U.S. companies to obtain cutting-edge technologies and intellectual property and generate the transfer of technology to Chinese companies." 55

19. China uses "corporate governance" law "as a tool to advance China's strategic goals, rather than simply, as is the custom of international rules, to advance the profitmaximizing goals of the enterprise." 56

20. China seeks to "obtain technology from American companies" by "intellectual property theft" and "cyber theft." 57 "Chinese security agencies have masterminded the wholesale theft of American technology — including cutting edge military blueprints." 58 "China conducts and supports unauthorized intrusions into, and theft from, the computer networks of U.S. companies to access their sensitive commercial information and trade secrets." 59

\section{Detailed Examination of US Complaints}

\subsection{Analytical Methodology}

Part 3 of this article examines the merits of the US complaints about China. Ideally, such an analysis would begin by analysing the veracity of each charge. Here, for reasons of space, such a factual examination is beyond the scope of this article. Yet for a few of the charges, the facts are clear enough to evaluate the validity of the charge.$^{60}$ For the rest of the charges, they will be presumed true even though in some instances the Trump Administration has put forward little or no corroborating evidence.

The Trump Administration's denouncement of China diverges from the usual practice in contemporary international relations of assuming good faith and expecting a complaining state to produce evidence for its allegation in an international body or in the court of public opinion. As the WTO Appellate Body has explained, "it is a generally accepted canon of evidence in civil law, common law and, in fact, in most jurisdictions, that the burden of

${ }^{53}$ White House, Office of Trade and Manufacturing Policy, How China's economic aggression threatens the technology and intellectual property of the United States and the world, June 2018, p. 1.

${ }^{54}$ White House, Office of Trade and Manufacturing Policy, How China's economic aggression threatens the technology and intellectual property of the United States and the world, June 2018, p. 4.

${ }^{55}$ USTR, Notice of Determination of Action Pursuant to Section 301, 83 F.R. 14907, 6 April 2018.

56 White House, Office of Trade and Manufacturing Policy, How China's economic aggression threatens the technology and intellectual property of the United States and the world, June 2018, p. 11.

${ }^{57}$ White House, President Donald J. Trump is Confronting China's Unfair Trade Policies, 29 May 2018; Mike Pompeo, Remarks by Secretary Pompeo on America's Economic Revival at Detroit Economic Club, 18 June 2018.

${ }^{58}$ White House, Remarks by Vice President Pence to the Hudson Institute on the Administration's Policy Toward China, 4 October 2018.

${ }^{59}$ USTR, Notice of Determination of Action Pursuant to Section 301, 83 F.R. 14907, 6 April 2018.

${ }^{60}$ See below Nos. 8 (Trade remedies), 9 (Data localization), 10 (Retaliation), and 12 (Trade deficit). 
proof rests upon the party, whether complaining or defending, who asserts the affirmative of a particular claim or defence." 61

For those charges for which the United States has not lodged a complaint at any international fact-finding body, the public could reasonably draw the adverse inference that the claim against China is untrue. That is because if it were true, the Trump Administration would have been eager to vindicate its claim before an independent fact-finding tribunal. Positing an adverse inference from non-litigation is especially appropriate in the WTO context because trade law makes use of adverse inferences.

With the top 20 charges now teed up, the study will proceed by analysing each of them. For each charge, the study will report on whether such behaviour by China violates WTO law. ${ }^{62}$ The study will also report on whether such behaviour by China is wrongful. A WTO violation is inherently wrongful. Yet, the indicated behaviour could also be wrongful - for example, for moral or economic reasons - even if the behaviour does not violate WTO law. Next, the study will consider whether WTO negotiations are needed to institute new norms to correct behaviour that is not WTO-illegal. If the WTO is not the right organization to craft such norms, the study will consider whether another international organization would be more suitable. For each charge against China, the study will note and evaluate the response being taken by the Trump Administration to remedy the problem. Finally, if a successful strategy is not currently being pursued, the study will point to a better strategy.

\subsection{The 20 Charges Individually Examined}

\section{Forced technology transfer.}

A Chinese government measure to force a US company to "hand over" its technology or trade secrets violates WTO law. Although the WTO Agreement on Trade-Related Intellectual Property Rights (TRIPS) permits compulsory licensing, a taking of foreign technology without compensation could violate TRIPS Articles 26, 28, 36, and 39. A taking of trade secrets could violate TRIPS Article 39.2.

Besides the regular TRIPS rules, China has numerous additional WTO accession obligations that apply only to China. These applicant WTO-plus obligations are found in China's Accession Protocol ${ }^{63}$ and Working Party report. ${ }^{64}$ Two unique obligations in the Working Party report (paras. 49, 203) prohibit forced technology transfer. ${ }^{65}$

The Trump Administration has not lodged a WTO case against China regarding charge No 1. Instead, the Administration maintains that "Many of the worst actions undertaken by China - such as the numerous informal methods of pressuring U.S. companies to share their technology with Chinese partners - were not captured by China's obligations at the WTO."66

\footnotetext{
${ }^{61}$ United States - Measure Affecting Imports of Woven Wool Shirts and Blouses from India, Report of the Appellate Body, WT/DS233/AB/R, p. 14 (adopted 23 May 1997).

${ }^{62}$ When this article states that a measure by China or the United States violates the WTO, that is a prediction of what a WTO tribunal would rule should a well pleaded claim be brought to WTO dispute settlement.

${ }^{63}$ WTO, Protocol of the Accession of the People's Republic of China, WT/L/432, 23 November 2001.

${ }^{64}$ Charnovitz (2008); Ehring (2014).

${ }^{65}$ WTO, Working Party on the Accession of China, WT/ACC/CHN/49, 1 October 2001.

${ }^{66}$ USTR, 2019 Trade Policy Agenda and 2018 Annual Report, March 2019, p. 7.
} 
Count me as sceptical that a government can escape liability under WTO law merely by using informal pressure rather than formal pressure.

In its Section 301 action, USTR contends that "China uses foreign ownership restrictions, such as joint venture requirements and foreign equity limitations, and various administrative review and licensing processes, to require or pressure technology transfer from U.S. companies." ${ }^{67}$ Imposing such requirements, limitations, and processes is subject to the General Agreement on Trade in Services (GATS) to the extent that it implicates mode 3 commercial presence services. GATS Articles XVI and XVII contain disciplines for China that are supplemented by additional obligations in China's WTO-plus rulebook. Notwithstanding these causes of action, the Trump Administration has failed to lodge a GATS case against China.

In lieu of a legal challenge, the Trump Administration's strategy against forced technology transfer is to impose Section 301 sanctions. ${ }^{68}$ By forgoing WTO litigation, which would be the first-best instrument to secure constructive change in China, the Trump Administration is left only with inferior instruments. Even worse, because the Section 301 sanction violates WTO law, the Trump Administration undermines its narrative about China's misbehaviour. If a US sanction is considered to be politically necessary in US politics, then the sanction should have been crafted to be consistent with WTO law and to communicate that China's forced technology transfer is malum in se. In addition, the Administration could have championed new WTO negotiations to strengthen the rules against forced technology transfer by making clearer when ostensibly voluntary contracts cross the line into coercion.

\section{Chinese industrial policies.}

Public investment is often carried out via subsidies. An industrial policy using subsidies that cause adverse trade effects on other WTO members violates Article 5 of the WTO Agreement on Subsidies and Countervailing Measures (SCM). In my view, WTO antisubsidy law may be weaker in practice than it should be because of some regrettable DSB holdings that make it harder to show a financial contribution from a public body and to show a benefit from a subsidy to an enterprise. ${ }^{69}$ Nevertheless, WTO subsidy law remains robust. Moreover, in joining the WTO, China took on several stricter obligations regarding industrial policy subsidies as codified in its Protocol (para. 10.2) and Working Party report (paras. 167, 171-2).

Using export restraints violates GATT Article XI. China has already lost two WTO cases (Raw Materials and Rare Earths) regarding WTO-illegal export restraints. Moreover, China has tougher legal obligations on export restraints than do most (or all) other WTO members.

Thus, depending on the facts, a Chinese industrial policy utilizing subsidies or export restraints could violate WTO rules. Although disturbingly bereft of any legal analysis, the US International Trade Commission (USITC) issued a report in December 2017 holding that China's industrial policies on solar cells "directly contradicted the obligations that

\footnotetext{
${ }^{67}$ USTR, Notice of Determination of Action Pursuant to Section 301, 83 F.R. 14907, 6 April 2018.

${ }^{68}$ USTR, Notice of Determination of Action Pursuant to Section 301, 83 F.R. 14907, 6 April 2018.

${ }^{69}$ Ding (2014); Rovnov (2019).
} 
China committed to undertake as part of its WTO accession."70 The Trump Administration was quick to use the USITC report as justification to impose US tariff protection on solar cells, but the Administration did not pursue the cause of action against China suggested by the USITC.

Employing an industrial policy is not inherently wrongful. ${ }^{71}$ Indeed, an industrial policy that merely invites private investment in a key industry would neither be wrongful nor a WTO violation. When governments pursue industrial policy, the instrument of subsidy may be appropriate to provide social benefits, particularly in the presence of a market failure. Although the SCM Agreement recognizes the potentially constructive role of subsidies, ${ }^{72}$ there remains an unresolved legal tension between domestic policy space and the SCM disciplines that regulate such space. ${ }^{73}$

If governments limited their industrial policies to subsidies, the externalities could be manageable. Yet a common problem with industrial policy is that governments prefer cheaper means that use non-spending instruments such as trade measures. The use of import or export restraints can externalize high net costs on other countries.

The Trump Administration objects to China's pursuit of industrial policies to capture industries of the future, but from my perspective, such pursuit is a lot smarter than the Trump Administration's industrial policies to preserve industries of the past. The Administration's misuse of Section 232 tariffs to increase the capacity utilization of the domestic steel industry is naked industrial policy. Speaking of the effect of those steel tariffs, Trump has bragged that "what's happening with the steel industry is very exciting to me. It's being rebuilt overnight."74 The Administration's use of Section 201 tariffs to protect the washing machine and solar panel industries is another example of backwardlooking industrial policy. ${ }^{75}$

The Administration's claim that it is "unfair"76 for China to seek to take away domestic and international market share from the United States is facetious at best. Chinese producers have every right to compete to expand their market share just as US producers do. US producers have no vested right to their existing share of the domestic market or a foreign market. In a market-based economy, producers have to earn their share every day.

${ }^{70}$ Supplemental Report of the U.S. International Trade Commission Regarding Unforeseen Developments, 28 December 2017, https://solarbuildermag.com/wp-content/uploads/2018/01/ITC_Report_Suniva.pdf

${ }^{71}$ Charnovitz (1993-94), p. 88.

${ }^{72}$ See, for example, Articles 8 (expired), 25.3, 27.13, 27.14, 29.1.

${ }^{73}$ Meyer (2018), pp 538-539.

${ }^{74}$ White House, Press Conference by President Trump, 27 September 2018. More recently, Trump declared: "The steel industry is thriving now and it was dead when I came to office." White House, Remarks by President Trump at Signing of Executive Order, "Strengthening Buy-American Preferences for Infrastructure Projects," 31 January 2019.

${ }^{75}$ The import relief to those industries is questionable under US law which requires a path to "positive adjustment" and a showing that the relief will "provide greater economic and social benefits than costs." See 19 USC $\S 2251$ (a). Furthermore, the absence of US domestic judicial review of such import relief is in tension with GATT Article X:3(b).

${ }^{76}$ White House, What You Need to Know About President Donald J. Trump's Actions Responding to China's Unfair Trade Practices, 6 April 2018. 
USTR has not lodged a WTO case against China for the illegal use of either industrial subsidies or export restraints. ${ }^{77}$ This omission is especially puzzling because, as noted above, USTR argues that "China flouts the rules to achieve industrial policy objectives."78 So far, the Administration has failed to put foward any response to WTO-illegal subsidies and export restraints by China.

A scheme to utilize Section 301 sanctions against those subsidies would be problematic. Sanctions will be most effective when focused on one outcome and less effective when employed as a Swiss army knife ${ }^{79}$ to seek multiple outcomes. The utility of Section 301 sanctions may also depend on whether the target behaviour is itself wrongful as a violation of legal or other norms.

Another problem with the utility of Section 301 sanctions against China for subsidies or export restraints is the fact that China would call attention to the hypocrisy ${ }^{80}$ of the U.S. position, since the US government incessantly uses both subsidies and export restraints. Indeed in 2018, Congress and the Trump Administration worked together to strengthen the U.S. Department of Commerce's export control programs with the announced policy purpose of maintaining US leadership in science, technology, engineering and manufacturing. ${ }^{81}$

Establishing better disciplines for the use of industrial policy instruments such as subsidies, export controls, and technical barriers is a matter on which future WTO negotiations should focus. Yet defining proper versus improper industrial policies is quite difficult. For example, the Trump Administration's criticisms of the Made in China 2025 initiative $^{82}$ fail to take into account the positive externalities from China's green technology subsidies.

\section{Discriminatory or unjustified trade barriers.}

Non-tariff barriers (NTBs) and regulatory hurdles are neither inherently wrongful nor a violation of WTO law. Yet, they will be a violation of WTO law if they do not meet the stringent conditions in the Agreement on Technical Barriers to Trade (TBT) or the Agreement on the Application of Sanitary and Phytosanitary Measures (SPS). Discriminatory NTBs on products would be a violation of the TBT Agreement if the discrimination is not based on a legitimate regulatory distinction.

\footnotetext{
${ }^{77}$ A panel against China requested by the Obama Administration was composed at the beginning of the Trump Administration on the subject of China's agricultural support. The cause of action in this case is "support" under the WTO Agreement on Agriculture, not subsidies under the SCM Agreement. Recently, the panel report was released, and the panel found that China was out of compliance with the WTO Agriculture Agreement. China - Domestic Support for Agricultural Products, Report of the Panel, WT/DS511/R, circulated 28 February 2019.

${ }^{78}$ USTR, 2018 USTR Report to Congress on China's WTO compliance, February 2019, p. 8.

${ }^{79}$ Kahn R, Have sanctions become the Swiss army knife of U.S. foreign policy?. Council on Foreign Relations, 24 July 2017, https://www.cfr.org/blog/have-sanctions-become-swiss-army-knife-us-foreign-policy

${ }^{80}$ Bacchus J "Do as I say, not as I do": Trump's sizable China hypocrisy, The Hill, 25 January 2019, https://hehill.com/opinion/finance/426946-do-as-i-say-not-as-i-do-trumps-sizable-china-hypocrisy

8150 USC $\$ 4812$.

${ }^{82}$ USTR, Update concerning China's acts, policies and practices related to technology transfer, intellectual property, and innovation, 20 November 2018, p. 8.
} 
Oddly, the Trump Administration has not filed any TBT or SPS cases against China, and so the Administration misses an opportunity to demonstrate unfair and illegal actions by China affecting US exporters. NTBs do appear to be part of the ongoing US trade talks with China, and any deal reached will likely contain some ad hoc concessions by China. Yet by failing to frame the US agenda as seeking to get China to comply with the WTO's regulatory norms, the United States will likely fail to achieve systemic changes in the way that China writes its NTBs.

China's high tariffs are neither WTO-illegal nor wrongful per se. Of course, both China and the United States would be better off if China lowered its tariffs. The best way to secure that win-win outcome is through market access negotiations at the WTO. Unfortunately, USTR under the Trump (and Obama) Administration has not championed a successful conclusion of the WTO Doha Round tariff negotiations.

\section{Agricultural import bans.}

An import ban on agricultural products violates GATT Article XI:1 and is therefore wrongful. Back in August 2017, the Trump Administration lodged a WTO case (DS517) against China regarding tariff-rate quotas on wheat, rice, and corn. The lawsuit alleges that these quotas violate provisions in GATT and in China's accession agreement. ${ }^{83}$ In April 2019, the panel found multiple violations of China's accession obligations.

The Trump Administration has failed to lodge a WTO case against any Chinese agricultural import ban such as a ban on US poultry.

\section{Subsidies for added industrial capacity.}

The use of non-agricultural subsidies to promote capacity is an illegal SCM actionable subsidy if the production or export causes adverse effects on trading partners. A subsidy intended only to raise production distorts markets and is considered wrongful by the trading system, which prioritizes competing producer interests over consumer interests.

Although the terms "excess capacity" and "overproduction" are intended to be pejorative, the non-legitimacy of such conditions is contestable. In open, market-oriented economies driven by supply and demand, excess capacity and overproduction are normal phenomenon that are corrected by the market. If China produces more steel or aluminium than it will use domestically, such behaviour is not inherently wrong. For any commodity in an open world economy, one would expect that some countries would produce more than they need domestically and other countries would produce less than what they need. The WTO subsidy rules lay out what is legally improper, but that status does not necessarily match any economic concept of irrational or anti-competitive behaviour, or behaviour that externalizes trans-border costs.

If excessive global steel production causes social or employment problems, the most logical solution would be a multilateral commodity agreement negotiated outside of the WTO. The WTO recognizes the legitimacy of commodity agreements (in GATT Article XX(h)). In

${ }^{83}$ China - Tariff Rate Quotas for Certain Agricultural Products, Report of the Panel, WT/DS517/R, 18 April 2019. 
2016, the G-20 established a Global Forum on Excess Steel Capacity. Unfortunately, those global talks have been held without transparency so cannot be reported on in this study.

The Trump Administration has not lodged any WTO complaints to challenge China's subsidies that promote excess capacity. For steel, the Administration has responded to Chinese overcapacity by imposing protective tariffs under Section 232 (of the Trade Expansion Act) and by imposing numerous countervailing duties tied to injurious subsidies. Although the US steel tariffs have been effective in raising US capacity utilization, I have not seen any studies of whether the tariffs have reduced China's steelmaking capacity.

\section{Involuntary licensing requirements.}

Requiring US companies to license intellectual property at less than economic value is a WTO violation. To its credit, the Trump Administration has lodged a WTO challenge under TRIPS Articles 3 and 28. Nevertheless, USTR delayed in obtaining the WTO panel until late November 2018, over 15 months after Trump triggered a USTR Section 301 investigation and many months after USTR imposed unilateral sanctions.

This US litigation against China has been poorly executed. The cause of action in the current WTO panel (DS542) is too narrow because USTR neglected to bring licensing claims under paragraph 256 of the China Working Party Report. If China's licensing practices discriminate against the United States, then USTR also failed to bring claims under TRIPS Article 4. If China's licensing practices apply to other countries equally, then USTR missed an opportunity to recruit similarly affected WTO allies to join a case against China. WTO cases with multiple complainants typically do well before WTO tribunals.

\section{Non-Transparency.}

The WTO has two kinds of transparency requirements: domestic and international. The domestic requirements are for publication and disclosure in China for the benefit of domestic and foreign persons. The international requirements are for notification to the WTO for the direct benefit of other WTO Members and the indirect benefit of economic and social actors.

In 2019, USTR publicly reported its findings regarding "China's extremely poor record of adhering to transparency obligations as a WTO member." 84 So far, however, the Administration has filed only one WTO case against China regarding transparency, and that case (DS 517) covers only wheat, grain, rice, and corn. In mid-April 2019, the panel ruled against China.

This timid US litigation strategy is especially self-defeating since the United States was the leading proponent during China's accession negotiations for imposing numerous WTO-plus transparency rules in China's accession agreement that are tougher than the transparency requirements that apply to other WTO Members. ${ }^{85}$ The Trump Administration has roundly

${ }^{84}$ USTR, 2018 USTR Report to Congress on China's WTO compliance, February 2019, p. 3.

${ }^{85}$ Yamaoka (2013), pp. 153-156 (taxonomy). 
complained about the terms of China's entry into the WTO ${ }^{86}$ but the Administration has failed to take advantage of the many favourable terms for WTO incumbents (like the US) that provide for numerous WTO causes of action against China. The law of WTO transparency is already extensive, but certainly new WTO negotiations on transparency would be useful, including to universalize China's enhanced transparency obligations.

\section{Improper trade remedies.}

Trade remedies include antidumping, countervailing, and safeguard duties. As noted above, the Trump Administration complains that "China has been a particularly bad actor when it comes to trade remedies." 87 The record shows that in eight WTO cases, China was found to have violated trade remedy rules. ${ }^{88}$ None of those eight cases were brought by the Trump Administration, and during the Trump Administration, USTR has not lodged any new trade remedy cases against China. Other than vapidly labelling China a "bad actor," the Trump Administration has not put forward any strategy to address China's misconduct on trade remedies. Whether eight trade remedy violations by China renders that country a "bad actor" is a matter on which reasonable observers could differ.

No reasonable observer could doubt that the United States is a "bad actor" on trade remedies because the United States has lost an obscene number - currently 49 - WTO trade remedy cases brought against the US. ${ }^{89}$ Indeed, the United States is the WTO's most flagrant bad actor on trade remedies because the United States has lost far more trade remedy cases than any other WTO member has. ${ }^{90}$ During the Trump Administration, five new trade remedy cases against the US have been assigned to WTO panels. ${ }^{91}$ US Secretary of Commerce Wilbur Ross accuses China of "highly protectionist behaviour"92 without any sense of shame that the WTO-illegal trade remedies administered by the Commerce Department also afford protection.

Ideally, the WTO would carry out negotiations to better discipline improper trade remedies. Unfortunately, trade remedies have been embedded into the protectionist routines of many governments, and so this issue is probably too polarized for WTO legal reform to be achievable.

${ }^{86}$ In 2018, USTR declared that "it seems clear that the United States erred in supporting China's entry into the WTO on terms that have proven to be ineffective in securing China's embrace of an open, market-oriented trade regime." USTR, 2017 Report to Congress on China's WTO Compliance, January 2018, p. 2.

${ }^{87}$ USTR, 2018 USTR Report to Congress on China's WTO compliance, February 2019, p. 8.

88 WTO Cases 427, 483, $454+460,414,440,427,425,414$. Cases are listed in reverse chronological order of final decision. Cases that appear more than once involve follow-on compliance proceedings.

${ }^{89}$ WTO Cases 534, 523 (under appeal), 505 (under appeal), 437 (under appeal), 488, 471, 464, 429, 437, 436, $449,422,404,382,379,402,383,302+294,350,345,343,344,268,335,322,264,294,257,282,212$, $296,268,264,277,257,248+249+251+252+253+254+258+259,234,212,213,236,206,202,184$, $177+178,179,166,136+162,138,99$. Cases are listed in reverse chronological order of final decision. Cases that appear more than once involve follow-on compliance proceedings

${ }^{90}$ By way of comparison, the EU has lost 11 trade remedy proceedings: WTO Cases 486, 480, 442, 473, 397, 405, 337, 299, 219, 141 (twice).

${ }^{91}$ WTO Cases 436, 533, 534, 539, 536 (order of establishment).

92 China way more protectionist than US, says Trump official, South China Morning Post, 25 January 2018 , https:/www.scmp.com/news/china/article/2130520/china-way-more-protectionist-us-says-trump-official 


\section{Data localization.}

Data localization, that is, a governmental requirement to store data in the host country, can be one type of digital protectionism. ${ }^{93}$ No one disputes that China engages in digital protectionism. Indeed, the Digital Trade Restrictiveness Index finds China to have by far the most restrictive policy for digital trade..$^{94}$

The Trump Administration claims that China forces foreign companies to localize data within China. Data localization is not necessarily wrongful as there may be legitimate regulatory justification including privacy and public security. One recent study found that China's localization measures violate the GATS Agreement. ${ }^{95}$ So far, however, the Trump Administration has not lodged any GATS case against China. Other than labelling China a data localizer, the Trump Administration has not laid out any strategy to address China's practices on data localization.

The WTO has a role in policing digital protectionism because the WTO can be an arbiter of when domestic regulation is administered in a reasonable, objective, and impartial manner (see GATS Article VI:1). Nevertheless, WTO rules may not cover data itself, ${ }^{96}$ and the disciplines for the regulation of traded digital services may be narrower than the disciplines for regulation of products. At the time that GATS rules were written in the early 1990s, digital protectionism had not yet become an important international concern.

Back in 2001, I advocated WTO negotiations to open up internet market access. ${ }^{97}$ Little has been accomplished since then on that problem or the broader problems of digital trade barriers. The WTO's inability to make progress in the intervening years leads me to wonder whether the negotiation of such issues should be pursued in more specialised international fora rather than being reserved for the WTO.

The Trump Administration states that it is "initiating exploratory work on possible future negotiations" on digital trade. ${ }^{98}$ So far, however, the Administration's actions on data localization have been feeble. ${ }^{99}$ Indeed to date, the Administration failed to propose a set of comprehensive norms to address digital protectionism.

\footnotetext{
${ }^{93}$ Aaronson (2018), pp. 10-11.

${ }^{94}$ Ferracane MF et al., Digital Trade Restrictiveness Index. European Centre for International Political Economy, April 2018, pp. 6 (overall conclusion), 54-55 (China's data localization), https://ecipe.org/dte/dtereport

${ }^{95}$ Crosby D (2016), Analysis of data localization measures under WTO services trade rules and commitments. E15, March 2016, http://e15initiative.org/wp-content/uploads/2015/09/E15-Policy-Brief-Crosby-Final.pdf

${ }^{96}$ The WTO law status of digital trade is ambiguous. Data may be a WTO good or a service or both or neither. Many things with value, such as money and real property, are neither a good nor a service. Data may likewise not be a good or a service. Some clarification emerges from WTO legal text and subsequent practice. For example, when data is in an electronic form of something that is a good (like a book), then the electronic book is considered a good. The WTO agreement of 1998 to pledge not to impose customs duties on electronic transmissions (WT/MIN(98)/DEC2, 25 May 1998) may suggest that such transmissions are a good. That various GATS Agreements cover "data processing", "transfers of data", and "data transmission" may suggest that working on data is a service. GATS Article XIV(c)(ii) posits that regulation of the use of personal data is the regulation of a GATS service.

${ }^{97}$ Charnovitz (2001), p. 104.

98 https://ustr.gov/about-us/policy-offices/press-office/fact-sheets/2018/march/2018-fact-sheet-key-barriersdigital.

${ }^{99}$ USTR, 2019 Trade Policy Agenda and 2018 Annual Report of the President of the United States on the Trade Agreements Program, March 2019, Annual Report, p. 64.
} 


\section{China's retaliation.}

China is retaliating against both of the Trump Administration's unilateral tariffs imposed under Sections 232 and $301 .^{100}$ Each of these retaliatory actions violate WTO rules (especially GATT Arts. I and II) and, for that reason, the retaliation is wrongful. The Trump Administration has lodged a WTO case against China's Section 232 retaliation (DS 558), but has not brought a case against the Section 301 retaliation.

China commenced its Section 232 retaliation in April 2018, and at that moment, there was a good argument that China (and other countries) had the right to retaliate under WTO safeguard rules against the US steel tariffs that had begun in March 2018. ${ }^{101}$ After all, the title of Section 232 is "Safeguarding National Security"102 and Section 232 authorizes tariffs that are similar to the tariffs that could be employed in a conventional safeguard. Subsequently, however, the Appellate Body interpreted WTO safeguard law in a narrow way that had the effect of cutting out the ground under the argument for the legitimacy of retaliation against Section 232 tariffs.

The threshold question for Section 232 is whether it is a WTO safeguard. The legal case in support of China's retaliation against Section 232 tariffs was that the US tariffs are disguised safeguard tariffs for which an affected country can exercise retaliation rights under GATT Article XIX:3(a). Yet in August 2018, the Appellate Body held that to qualify as a WTO safeguard, a tariff increase "must be designed to prevent or remedy serious injury to the Member's domestic industry caused or threatened by increased imports" of the product. ${ }^{103}$ Although Section 232 provides a remedy against imports, the terms of Section 232 do not require either serious injury or increased imports. Because those prerequisites are absent from the statutory text of Section 232, a WTO panel considering such retaliation case will find that the Section 232 measures are not a safeguard and therefore that China's retaliation is illegal.

Given this subsequent development in WTO jurisprudence, China should withdraw its retaliation. The interposition of subsequent WTO case-law can render illegal a measure that was consistent with WTO law at the time it was instituted. This clarification in WTO law gives USTR a right to claim collateral estoppel from a new and unrelated WTO judicial holding. Ironically, the force of precedent in WTO jurisprudence - a common judicial practice now being opposed by USTR - will grant the United States a win in the ongoing Section 232 disputes at the WTO.

China's has also retaliated against the Section 301 tariffs. This retaliation flouts WTO law, particularly GATT Articles I and II and DSU Article 23. (USTR has not brought a WTO

${ }^{100} \mathrm{Lu}$ Z, Schott, Jeffrey J., How is China retaliating for US national security tariffs on steel and aluminum? Peterson Institute for International Economics (PIIE), 9 April 2018; Bown CP et al., China's retaliation to Trump's tariffs, PIIE, 22 June 2018.

101 Charnovitz S, EU can retaliate immediately against Trump's metal tariffs. 2 March 2018, https://worldtradelaw.typepad.com/ielpblog/2018/03/eu-can-retaliate-immediately-against-trumps-metaltariffs.html

10219 USC $\S 1862$.

103 WTO, Indonesia - Safeguard on Certain Iron and Steel Products, Report of the Appellate Body, WT/DS490, 496 (adopted 27 August 2018), para. 5.60. 
case against China for this retaliation. ${ }^{104}$ ) China's impulse to hit back is understandable, but the tariffs are legally wrongful and China should repeal its retaliation. China's retaliation may also lead to serious environmental consequences from distorting trade. ${ }^{105}$

The Trump Administration responded to China's retaliation against Section 301 tariffs by USTR's decision to impose $\$ 200$ billion in additional Section 301 tariffs on China. This response shows that China's illegal retaliation was a blunder because it gave the United States an excuse to quadruple down on Section 301 sanctions. The Trump Administration sees itself in a winning position because there are much higher imports from China into the US than from the US into China.

The second tranche of Section 301 tariffs is just as WTO-illegal as the first tranche was. No unilateral tariffs imposed via Section 301 could ever be legal under WTO rules unless imposed as a DSB-authorized suspension of concessions or other obligations (SCOO). To its credit, China lodged a WTO case against the Section 301 tariffs (DS543), but so far, China has held off on securing the appointment of a panel. This delay may be politically connected to the Trump Administration's demand in ongoing US-China bilateral trade talks for China to agree not to bring future WTO challenges against US unilateral enforcement of the prospective China-US deal.

\section{Lack of market-oriented policies.}

The Trump Administration complains that China's economic policies since joining the WTO have not met the expectations of the United States and other WTO members. According to USTR, "When China acceded to the WTO in 2001, it voluntarily agreed to embrace the WTO's open-market-oriented approach and embed it in its trading system and institutions." 106 Furthermore, "Through China's commitments and representations, WTO members understood that China intended to dismantle existing state-led, mercantilist policies and practices...." 107 These complaints raise the fundamental question of what duty China owes to the WTO regarding China's economic and trade policies.

To analyse this question, one should start with general WTO law. Contrary to the suggestions of the Trump Administration, the WTO does not require its members to adhere to any particular economic or political system. Nowhere does the WTO Agreement define the role of the state in relation to the market or civil society. The WTO rule that may come the closest to addressing economic systems is SCM Article 29 (Transformation into a Market Economy), but this provision stops short of requiring a government to effectuate such a transformation. Nor does the WTO constitution contain a provision to expel a Member that renounces market-oriented policies.

Although joining the WTO by accession does not in itself entail any special responsibilities regarding market friendliness, China's accession agreement does cover aspects of its economic system. For example, China reported that it had the objective of establishing and

\footnotetext{
${ }^{104}$ But consultations are ongoing in DS565.

105 Sax S, Millions of acres of the Amazon are at risk due to the trade war between the U.S. and China, Pacific Standard, 18 April 2019, https://psmag.com/economics/amazon-could-be-biggest-casualty-of-us-china-tradewar

106 USTR, 2018 USTR Report to Congress on China's WTO compliance, February 2019, p. 5.

${ }^{107}$ USTR, 2018 USTR Report to Congress on China's WTO compliance, February 2019, p. 5.
} 
improving the socialist market economy. ${ }^{108}$ But China's Accession Agreement does not commit China to adopt "market-oriented" policies and mentions that term only in one sentence wherein China notes that it is "undertaking market-oriented reform in the agricultural sector." ${ }^{109}$ China's Accession Agreement does not contain any commitment by China to transform its economy or to abandon mercantilism. The Trump Administration is trying to insinuate rules into China's Accession Agreement that it wishes were there, but are not.

The issue of how broadly to interpret applicant WTO-plus accession obligations has occasionally arisen in WTO dispute settlement. In my view, such obligations should be interpreted narrowly contra proferentem. Under this principle, if a provision in a contract is ambiguous, then the tribunal should adopt an interpretation that works against the party who drafted that wording in the contract.

To apply this concept to the WTO, the China Accession Agreement is a contract-like international agreement between the WTO and China drafted by the WTO and agreed to by China. Although the applicant China had a role in accession negotiations, the key documents were drafted by WTO Members (led by the United States) in WTO bodies that did not include China.

In seeking to join the WTO, China made hundreds of detailed accession commitments. To quote a contemporary WTO Secretariat posting, "As a result of this negotiation, China has agreed to undertake a series of important commitments to open and liberalize its regime in order to better integrate in the world economy and offer a more predictable environment for trade and foreign investment in accordance with WTO rules." ${ }^{110}$ In my view, China should be held to those "important commitments" which is why this article has expressed disappointment that the Trump Administration has brought only one accession-based complaint against China. Yet, holding China to its own commitments is quite different from asserting that China has failed to keep promises that China in fact did not make.

In my view, the Trump and Obama Administration should have lodged more cases against China based on China's extraordinary accession commitments. For the Administration to call China a WTO violator without backing up that assertion in a tribunal of law evidences cowardice if not dishonesty. The best litigation strategy for the US would have been to file a series of cases under each of the WTO agreements. But if the Administration had also chosen to push the envelope by filing a broad case against China for its "state-led, mercantilist approach to the economy and trade," ${ }^{111}$ I would have supported that too.

Disciplining large non-market economies is a difficult challenge for the trading system. Rather than use the WTO, the Obama Administration pursued a flawed geopolitical strategy to craft better rules in the TPP and then to seek to pressure China into adhering to these rules. This strategy was flawed for three reasons: First, the rules achieved in the TPP fall far short of the market economy rules needed to transform the alleged pathologies in China's economy. Second, the idea of refusing to invite China to join the TPP and then seeking to isolate China economically was delusional given China's size as the world's largest trader.

\footnotetext{
${ }^{108}$ WTO, Working Party on the Accession of China, WT/ACC/CHN/49, 1 October 2001, para. 6.

${ }^{109}$ WTO, Working Party on the Accession of China, WT/ACC/CHN/49, 1 October 2001, para. 115.

110 WTO, WTO Ministerial Conference approves China's Accession, 10 November 2001, https://www.wto.org/english/news_e/pres01_e/pr252_e.htm

${ }^{111}$ USTR, 2018 USTR Report to Congress on China's WTO compliance, February 2019, p. 2.
} 
Third, the tactic was naive politically in ignoring China's historic sensitivity to rules being foisted on it through unequal treaties. A further flaw in Obama's TPP containment strategy was the failure of his Administration to garner US public support for the TPP project. Notably, all of the leading presidential candidates to succeed Obama opposed Obama's TPP.

Choosing the extent of market-oriented policies is a matter that WTO subsidiarity leaves to governments. While governments need not be clones of each other, there is a role for trade agreements to nudge governments toward best practices in regulation, deregulation, and privatization. In some areas, tight rules may be useful, but in others, governments should be able to retain their diversity and policy space. While internationally-agreed norms play an important role in improving domestic policies, such norms should not seek to displace the role of competition between countries as a way to get governments to lift standards.

\section{High bilateral trade deficit.}

President Trump has constantly complained about the high US trade deficit with China. In 2018 , the bilateral goods deficit was $\$ 419$ billion, the highest level ever. ${ }^{112}$ A bilateral trade deficit in goods is not wrongful per se and is not WTO-illegal. The US trade deficit with China may be more interesting than the US deficit with Chad, but that is only because China is much bigger than Chad, not because the US-China deficit is a meaningful policy target. Although the Trump Administration complains about state-led mercantilism, nothing can be more mercantilist than the demands of the Administration for the bilateral trade balance with China to be "more equitable."113

All things being equal, a higher trade deficit in goods and services wreaks greater negative impact on domestic import-competing industry than a lower trade deficit does. The most meaningful bilateral trade numbers cover both goods and services, and in 2018, that goods and services deficit with China was $\$ 379$ billion. ${ }^{114}$ Thus, undertaking structural economic changes that would lower the $\$ 379$ billion deficit with China is a good idea.

A US trade deficit with China means that US consumers and producers buy more from China than Chinese consumers and producers buy from the United States. The least coercive way to address this imbalance is for the United States to expand US exports of goods and services to China. By contrast, direct action to reduce US imports from China entails coercion and infringes freedom.

Many targeted policy reforms to expand US exports have been suggested. For example, the US government could reduce its gargantuan budget deficit, which has been expanding under the Trump Administration. A budget deficit pulls in foreign capital that cannot be used to purchase US exports. The US government could make US exports more competitive by reducing production costs stemming from underinvestment in infrastructure, underinvestment in Chinese language training, and overregulation of US companies. The US government could also eliminate unnecessary US export controls. Trump's new tariffs on China have had the indirect effect of reducing Chinese demand for high-tech US products such as iPhones. That provides yet another reason to withdraw the Section 301 tariffs.

\footnotetext{
$112 \mathrm{https} / /$ www.census.gov/foreign-trade/balance/c5700.html

${ }^{113}$ White House, Statement from the President Regarding Trade with China, 18 June 2018.

114 https://www.bea.gov/system/files/2019-03/trad0119.pdf (BOP basis)
} 
Unfortunately, the Trump Administration is not pursuing any of those constructive remedies to boost US exports. Instead, the Trump Administration appears to be using two tactics to lower the US trade deficit with China.

First, the President is asking China for a purchase agreement with monetary import targets for US goods. ${ }^{115}$ This request is cynical because the Administration on one side of its mouth is demanding that the Chinese government exercise greater management of its trade while on the other side of its mouth, the Administration demands that the Chinese government be more market-oriented and less statist. The request is also problematic for third parties because if China commits to importing more from the US, then China may reduce imports from other WTO member countries. Any quantitative US-China trade agreement may run afoul of Article 11.1(b) of the WTO Safeguards Agreement which forbids arrangements involving "export or import surveillance" when such arrangements afford protection. In addition, should China's government intervene to dictate the origin of goods purchased by state-invested or state-owned enterprises, that would violate one of China's accession commitments. ${ }^{116}$

The second tactic is to impose tariffs on China in order to lower imports from China. That result has not clearly happened yet, but with a high enough tariff, it would. One thing that is clear is that most of the Trump Administration's new tariffs against China violate WTO rules. The Section 301 tariffs violate GATT Articles I and II. The Section 232 tariffs violate GATT Articles I and II and are not justified under the national security exception in GATT Article XXI. ${ }^{117}$ The Section 201 tariffs on washing machines violate GATT Article XIX because the US government failed to make any determination on "unforeseen developments." The US safeguard on solar panels may also violate GATT Article XIX.

China's high trade surplus with the United States should be subject to WTO tariff negotiations. Unfortunately, the Trump Administration has not shown any interest in the Doha Round or a renamed new trade round. China agreed to lower its tariffs and other barriers as part of its accession negotiations circa 1999, but 20 years later, China should do so again. Likewise, over 25 years after the conclusion of Uruguay Round tariff negotiations, a new round of liberalization by the United States is long overdue.

\section{Unharmonized tariffs and taxes.}

Trump's call for China and US tariffs and taxes to be mirrored or reciprocal is perhaps his most perverse recommendation. For the United States to fail to match China's taxes and tariffs is hardly wrongful. Nor are non-matching taxes and tariffs a violation of WTO rules. Certainly, the US and China could negotiate tariff and tax bindings within the WTO to seek fiscal harmonization. What cannot be done is for China and the US to harmonize higher

115 White House, Remarks by President Trump at Signing of a Presidential Memorandum Targeting China's Economic Aggression, 22 March 2018; Sukin G, Mnuchin says China will buy \$1.2 trillion in U.S. goods, 22 February 2019, https://www.axios.com/us-china-currency-deal-trump-trade-war-0d1f5de8-26f5-42f1-becd102f8106b67c.html

${ }^{116}$ WTO, Working Party on the Accession of China, WT/ACC/CHN/49, 1 October 2001, para. 46. A measure mandating the importation of goods from a favoured country is an GATT Article I violation.

117 Charnovitz (2018), pp. 239-240; Pinchis-Paulsen M, Trade multilateralism and national security: Antinomies in the history of the International Trade Organization, 2019, https://papers.ssrn.com/sol3/papers.cfm?abstract_id=3353426 
tariffs and taxes on each other because that would violate the most-favoured-nation (MFN) rule.

The idea that the United States would delegate to China the setting of US tax and tariff levels is fiscally unwise. Allowing China to determine US fiscal policy is also a violation of US constitutional principles of self-government. This deference to China is a surprising recommendation for the Trump Administration which has declared that: "Trade policy, like tax policy, must reflect the wishes, concerns, and priorities of the American people - and should not be dictated by technocrats who are not responsible to Americans. The United States remains an independent nation, and our trade policy will be made here - not in Geneva." 118 Made in Washington except when Trump calls for US taxes and tariffs to be made in Beijing!

The Trump Administration is right in suggesting that China should lower its high tariffs. This is the sort of goal that could properly be addressed in a new round of WTO negotiations. Unfortunately, Trump's USTR (and before it Obama's USTR) failed to press for such negotiations.

If China and the US had a free trade agreement (FTA), then the tariffs of both countries could be harmonized to zero. The goal of joining China in an FTA has never been suggested by the Trump Administration. Indeed, in the negotiations for a new trade agreement between Canada, the United States, and Mexico, the Trump Administration insisted on adding a new provision (Article 32.10) to discourage any North American country from negotiating an FTA with China. ${ }^{119}$

\section{Belt and Road.}

The Belt and Road Initiative (BRI) is China's major international development investment initiative to expand trade-related foreign infrastructure. BRI is designed not only to expand China's trade, but also to promote development and connectivity to many countries around China. Begun only six years ago, BRI is already having a major economic and political impact. Countries that need to improve their infrastructure are signing on despite misgivings. ${ }^{120}$

Since BRI does not directly involve the United States, the carping at BRI by the Trump Administration can only be the result of envy at the leadership, deep pockets, and administrative prowess shown by China. No question, the Trump Administration has a lot to envy because it is failing to achieve any major infrastructure program abroad or at home. For the Trump Administration, ambitious infrastructure means a wall at the Mexican border and even that ill-advised project is not being achieved.

USTR's complaint that BRI "fails to adhere to internationally accepted best practices in infrastructure development and government procurement" ${ }^{121}$ leads to some questions: Do

\footnotetext{
${ }^{118}$ USTR, 2019 Trade Policy Agenda and 2018 Annual Report, March 2019, p. 27.

${ }_{119}$ Blanchfield M, Beijing attacks USMCA clause seen as blocking efforts to expand trade with Canada, Mexico. 5 October 2018, https://www.cbc.ca/news/politics/usmca-nafta-china-trade-1.4852269

${ }^{120}$ Lau S, Italy may be ready to open up four ports to Chinese investment under "Belt and Road Initiative". 19 March 2019, https://www.scmp.com/news/china/diplomacy/article/3002305/italy-may-be-ready-openfour-ports-chinese-investment-under

${ }^{121}$ USTR, 2018 USTR Report to Congress on China's WTO compliance, February 2019, p. 15.
} 
the United Nations Sustainable Development Goals 17.1-17.5 cover best practices in development financing? What are "best practices" in infrastructure development? How much of the success of BRI is owed to the inadequacy of development financing from advanced economies? Such questions are important, but cannot be explored here.

However well or poorly China follows best practices in development financing, very little of that touches on WTO law. Indeed, subsidies to foreign countries are omitted from coverage in the SCM Agreement. Thus, China's failure to follow best practices in BRI is not wrongful in world trade law. In my view, the best practice mostly missing from BRI is that China has not built a sustainable development dimension into BRI and has not laid out a good plan to conduct environmental impact analysis. ${ }^{122}$

Two respected international legal scholars, Julien Chaisse and Mituso Matsushita, view BRI as a way for China "to export its development model. ${ }^{123}$ Certainly, the broad scope of BRI turns it into a transnational issue for which China should engage in negotiations with key governments and international organizations. Based on the scope of BRI, the WTO seems an inapposite forum for such negotiations.

So far, the Trump Administration has not instituted any trade actions specifically against BRI. The main response by the Administration to BRI has been to work with the US Congress to enact a new law to improve US development finance programs. ${ }^{124}$ The BUILD Act seeks to reorganize federal agencies with responsibilities for development finance and to expand US funding. ${ }^{125}$ The Act takes a step in the right direction of competing with China rather than coercing it.

\section{Lax environmental standards.}

The Trump Administration complains that China's lax environmental standards and weak enforcement of them helps China "dominate traditional manufacturing industries." ${ }^{26}$ The theory that lax environmental, health or safety standards can drive national economic success is controversial, and growing evidence shows that a business can enhance its competitiveness by improving environmental sustainability. ${ }^{127}$ For a government to maintain unjustifiably low environmental standards is wrongful, but such behaviour is not regulated by the WTO.

The WTO did include fishery subsidies as a Doha Round issue, but that issue was a poor fit for the WTO. In general, environmental challenges should be addressed in international environmental fora and fishery challenges should be addressed in international fishery fora. As the eminent environmentalist Konrad von Moltke pointed out decades ago, an environmental issue migrates to the trading system only when it is not being successfully managed within the appropriate international regime.

122 Murase S, "Belt and Road" from the viewpoint of international law. Unpublished manuscript 2018.

${ }^{123}$ Chaisse and Matsushita (2018), p. 163.

${ }^{124}$ Chatzky A, McBride J, China's massive Belt and Road Initiative, Council on Foreign Relations, 21 February 2019.

125 Even if the proposed $\$ 60$ billion level funding level were approved by the US Congress (which seems doubtful), the US government funding would remain substantially less than the Chinese government funding.

${ }^{126}$ White House, Office of Trade and Manufacturing Policy, How China's economic aggression threatens the technology and intellectual property of the United States and the world, June 2018, p. 1.

127 Esty (2019). 
Many FTAs contain commitments regarding the enforcement of domestic environmental standards. For example, the Comprehensive and Progressive Agreement for Trans-Pacific Partnership (CPTPP) directs that "a party shall not waive or otherwise derogate from [...] its environmental laws in a manner that weakens or reduces the protection afforded in those laws in order to encourage trade or investment between the Parties." ${ }^{128}$ At this time, neither China nor the United States is a party to the CPTPP. ${ }^{129}$ To my knowledge, no FTA has regulated the level of environmental standards (except to incorporate norms in mutually agreed multilateral environmental agreements).

Whether the environmental, health, and safety standards of China and the United States are set at the right level is a proper matter of mutual interest especially when standards cover global issues, such as ocean pollution, air pollution, or waste. Lowering environmental standards can raise trade concerns, but so can the raising environmental standards. For example in 2018, China imposed a ban on recycled imports and plans a future ban on rubbish imports. ${ }^{130}$ This action directly affects the US economy because China has been a major destination for US recycling and trash exports.

\section{Securing natural resources.}

The Trump Administration complains that China uses a predatory debt trap model to secure natural resources. Depending on the facts as to predation and trapping, this may be wrongful behaviour. On the other hand, an ungenerous lending practice is not a WTO violation. Moreover, I am not aware of any pertinent international legal norms that cover such behaviour other than on tied aid.

Certainly, appropriate sovereign lending terms are a topic ripe for multilateral or regional negotiations. The World Bank, the United Nations Conference on Trade and Development (UNCTAD), and the Development Assistance Committee of the Organisation for Economic Co-operation and Development (OECD) could each be an appropriate forum for these discussions. In my view, the WTO would not be the right forum for those issues other than when related to trade governance capacity.

\section{Global misallocation of resources.}

The Trump Administration complains that China is misallocating global resources in a way that leaves everyone poorer. The proper allocation of resources is a key economic function typically left to markets. The Preamble to the WTO Agreement suggests that governments,

${ }^{128}$ Comprehensive and Progressive Agreement for Trans-Pacific Partnership (CPTPP), 3 March 2018, Article 20.3.6.

${ }^{129}$ After the Trump Administration pulled the US out of the TPP, the remaining 11 nations renamed the Agreement as "Comprehensive and Progressive" and, in true Orwellian fashion, made it less comprehensive by suspending 22 provisions on investment and intellectual property that had been championed by the US. Goodman MP, From TPP to CPTPP. CSIS, 8 March 2018, https://www.csis.org/analysis/tpp-cptpp

${ }^{130}$ A Chinese ban on rubbish imports is shaking up the global junk trade, The Economist, 29 September 2018, https://www.economist.com/special-report/2018/09/29/a-chinese-ban-on-rubbish-imports-is-shaking-up-theglobal-junk-trade 
in their trade relations, should be "allowing for the optimal use of the world's resources in accordance with the objective of sustainable development [...]."131

Notwithstanding that norm, the WTO has no rules regarding the proper allocation of resources. Adding such an issue to the WTO's agenda would not be a good idea because the WTO's agenda is already overloaded. Moreover, the WTO has performed poorly in negotiating numerous issues much more central to the WTO's mission.

The beauty of markets is that they handle a task like allocating resources through the gainful and voluntary interaction of private actors. Allocation bureaucrats are not needed. The Administration's complaint seems to be that allocation decisions in China are too often being made administratively rather than in the market. Obviously, China could lodge the same complaint against the US given the numerous non-market allocations being imposed by the Trump Administration.

The White House contends that a misallocation of resources can leave the Chinese people poorer than they would be in a world of efficient markets. In defending its economic aggression against China, USTR argues that "the distortions caused by China's non-market system" are bad not only for the United States, but for China too. ${ }^{132}$ I agree with both contentions and with USTR's similar claim that reforms in China to pursue an "open, market-oriented approach" will "also benefit China, by placing its economy on a more sustainable path [...]."133 The Trump Administration's insight is supported by the enlightened private sector. For example, Jamie Dimon, in his annual letter to JPMorgan Chase stockholders, recently explained: "We should only expect China to do what is in its own self-interest, but we believe that it should and will agree to some of the United States' trade demands because, ultimately, the changes will create a stronger Chinese economy."134

The paradox in this pressure on China to swallow its economic medicine is that given how competitive ${ }^{135}$ China now is against the United States with one hand tied behind its back due to distorted allocations, who knows how much more economically powerful China would become once it improves its suboptimal economic policies.

The worst misallocation of resources occurring in the world today is the excessive reliance on energy from fossil fuels. Such behaviour is wrongful in view of what scientists warn about the effects of carbon energy on climate change. The Trump Administration supports "promoting more efficient markets," ${ }^{136}$ but the world's most egregious market inefficiency is the failure to internalize the costs of utilizing carbon energy. Neither China nor the US has appropriate carbon internalization policies.

Instituting carbon charges falls within the wheelhouse of the climate regime. So far, the Paris Agreement has avoided instituting such policy norms. Even if one considers this

131 Agreement Establishing the World Trade Organization, Preamble, 15 April 1994.

132 USTR, 2018 USTR Report to Congress on China's WTO compliance, February 2019, p. 6.

${ }^{133}$ USTR, 2018 USTR Report to Congress on China's WTO compliance, February 2019, p. 5.

134 Annual Report 2018, April 2019, https://reports.jpmorganchase.com/investor-relations/2018/ar-ceoletters.htm? $\mathrm{a}=1$

${ }^{135}$ According to the latest IMF projections, the growth rate for China in 2019 will be $6.3 \%$ as compared to the US growth rate of 2.3\%. See World Economic Outlook, April 2019.

${ }^{136}$ USTR, 2019 Trade Policy Agenda and 2018 Annual Report of the President of the United States on the Trade Agreements Program, March 2019, p. 2. 
stance a failure in climate policy (as I do), no one should look to the WTO as a substitute forum for negotiating climate policies such as carbon charges or border adjustments.

\section{China's acquisitions in US.}

The Trump Administration complains that China directs and unfairly facilitates investment and acquisition to generate large-scale technology transfer from U.S. companies to Chinese entities. Neither outward foreign investments nor inward foreign investments are intrinsically wrongful in a global economy. Indeed, the movement of capital and technology across borders are normal processes that benefit both capital exporting and capital importing countries.

The WTO is largely silent on the international acquisition of technology, but there is some soft law favouring openness. One WTO agreement calls on governments to "facilitate investment across international frontiers so as to increase the economic growth of all trading partners [...]."137 Another WTO agreement suggests that developed countries "should provide incentives to enterprises and institutions in their territories for the purpose of promoting and encouraging technology transfer to least developed country Members in order to enable them to create a sound and viable technological base." 138

The limited international investment law obligations in the WTO need to be read in conjunction with the extensive discretion that remains with national regulators to control inward foreign investment and acquisition of domestic enterprises and technologies. WTO rules would permit a government to bar inward foreign investment and foreign acquisition of domestic technology. Barring the importation of capital from one country, but not others, is subject to being examined pursuant to the non-discrimination rules of GATS Article II.

If the Trump Administration wants to bar Chinese entities from making certain investments in the US or transferring technology back to China, then the US government would have prescriptive jurisdiction to enact and enforce national laws to accomplish that objective. Such laws are reviewable under WTO rules, but the United States has nearly complete discretion under the WTO to enforce such laws against China. The TRIPS Agreement regulates the protection of alien intellectual property, but the TRIPS Agreement does not mandate free trade in domestic intellectual property and technology.

The Trump Administration is imposing Section 301 tariffs to punish China's efforts to invest in the United States, to acquire US companies that have cutting-edge technologies, and to transfer such technology back to China. ${ }^{139}$ As noted above, the use of Section 301 tariffs violates US obligations in the WTO.

But not only are Section 301 tariffs internationally illegal, they are also grossly inefficient in targeting China's actions in the US. By far, the most effective instrument for the United States to use to regulate China's actions within the US territory is domestic regulation. For a sanctioning addict like the United States to waste sanction-sending resources to achieve a purpose that can be fully achieved under domestic law is feckless. The same point applies in No. 20 below.

${ }^{137}$ WTO Agreement on Trade-Related Investment Measures, Preamble.

138 TRIPS Article 66.2.

${ }^{139}$ USTR, Notice of Determination of Action Pursuant to Section 301, 83 F.R. 14907, 6 April 2018. 
The particular domestic law that the United States uses to control foreign investments is notoriously unfair. The regulator is the President and the Committee on Foreign Investment in the United States (CFIUS) who together can review foreign investments affecting national security broadly defined. CFIUS is a committee of federal officials without any public members. In CFIUS proceedings, neither the applicant foreign person nor the domestic counterparty enjoy any rights. Worse yet, the regulator has untrammelled discretion. The closed nature of the process makes it difficult for the public to see how arbitrarily foreign entities are being treated.

Under the Trump Administration, the outrageous CFIUS process has gotten even worse following a new federal law passed by the Congress in 2018 that denies judicial review of the President's findings or actions. ${ }^{140}$ The recent ramping up of US regulation of domestic enterprises seeking foreign investment violates market principles ${ }^{141}$ and demonstrates the need for new international rules to discipline CFIUS-style regulations. ${ }^{142}$

\section{Corporate governance law.}

The Trump Administration complains that China uses corporate governance law "as a tool to advance China's strategic goals, rather than simply, as is the custom of international rules, to advance the profit-maximizing goals of the enterprise." 143 Of the 20 claims reviewed here, this claim is the most fatuous. As noted above, this article does not attempt to reach the truth as to what is occurring in China. Thus, I will assume that China is using its corporate law to advance China's strategic goals. Corporate law, like any law, exists for the purpose of promoting the public interest.

The Trump Administration claims that there is an international custom or international rule that enterprises should only advance their profit-maximizing goals. No evidence is put forward for that claim and I do not know of any. Certainly, the WTO does not have a rule mandating or suggesting that enterprises should maximize their profits. In the United States, no federal or state law assigns enterprises the duty of maximizing their profits.

In a recent restatement of the basic principles of corporate law around the world, a group of experts explained:

Contrary to widespread belief, corporate directors generally are not under a legal obligation to maximise profits for their shareholders. This is reflected in the acceptance in nearly all jurisdictions of some version of the business judgment rule, under which disinterested and informed directors have

\footnotetext{
14050 USC $\S 4565(\mathrm{e})(1)$.

${ }^{141}$ See Joint Statement on Trilateral Meeting of the Trade Ministers of the United States, Japan, and the European Union, Annexed Statement 3, Joint Statement on Market Oriented Conditions, 31 May 2018 ("The Ministers noted the following elements or indications that signal that market conditions exist for businesses and industries: [...] (2) decisions of enterprises on investments are freely determined and made in response to market signals;..."), https://ustr.gov/about-us/policy-offices/press-office/press-releases/2018/may/jointstatement-trilateral-meeting

${ }^{142}$ Klein JX, It's not just the U.S.: Around the world, doors are shutting on Chinese investment. South China Morning Post, 13 September 2018, https://www.politico.com/story/2018/09/13/china-us-investment-788834

${ }^{143}$ White House, Office of Trade and Manufacturing Policy, How China's economic aggression threatens the technology and intellectual property of the United States and the world, June 2018, p. 11.
} 
the discretion to act in what they believe to be in the long-term interests of the company as a separate entity, even if it does not entail seeking to maximize short-term shareholder value. ${ }^{144}$

I do not know what the latest trends are in Chinese corporate governance, but contrary to the claim of the Trump White House, if China is seeking to steer companies to pursue goals other than profit maximizing that would not place China out of the comparative mainstream nor diverge from the US approach. If instead of leaving corporate goals up to each company, China were to task its corporations to pursue sustainability and decent work and to refrain from corruption, such corporate law would not appear to impose any harm on the US economy.

\section{Cyber and intellectual property theft.}

The Trump Administration complains that China's government engages in "theft" of American technology. Such theft is illegal under U.S. law. Rather than improving enforcement of federal law, however, the Trump Administration in July 2018 imposed Section 301 tariffs on China to counter the thefts. Finally, in an apparent afterthought, the Administration began stepping up high-profile domestic enforcement actions against Chinese entities. ${ }^{145}$

A proposition that either theft and espionage violates WTO law seems doubtful, but I reserve judgment. No doubt exists that a Section 301 tariff against theft and espionage violates WTO law. Using the Section 301 instrument is especially paradoxical for a purpose for which straightforward penalties such as US criminal prosecutions are available. Whether US criminal law provides sufficient deterrence against perpetrators beyond the reach of US courts is a matter that should be considered. Some analysts have suggested that indicting wrongdoers is not sufficient, and that non-tariff sanctions against the responsible Chinese perpetrators are needed. ${ }^{146}$

The analysis above of Trump's top 20 gripes about China's trade practices is summarized in Table 1 below:

\footnotetext{
144 The modern corporation, Statement on company law, October 2016, https://papers.ssrn.com/sol3/papers.cfm?abstract_id=2848833

${ }^{145}$ Yap, C-W, U.S. weaponizes its criminal courts in fight against China and Huawei, Wall Street Journal, 17 January 2019.

${ }^{146}$ Barfield C, New China intellectual property indictments: A step forward and a cop-out. AEI, 7 January 2018, http://www.aei.org/publication/new-china-intellectual-property-indictments-a-step-forward-and-acop-out/
} 
Table 1

Key Aspects of Trump's Top 20 Complaints About China's Behaviour

\begin{tabular}{|c|c|c|c|c|c|}
\hline Complaint & $\begin{array}{l}\text { Is behaviour } \\
\text { wrongful? }\end{array}$ & $\begin{array}{l}\text { Does this } \\
\text { behaviour } \\
\text { violate WTO? }\end{array}$ & $\begin{array}{l}\text { Did } \\
\text { Trump } \\
\text { lodge } \\
\text { WTO } \\
\text { case? }\end{array}$ & $\begin{array}{l}\text { Are new WTO } \\
\text { negotiations } \\
\text { necessary? }\end{array}$ & $\begin{array}{l}\text { Are } \\
\text { negotiations } \\
\text { outside the } \\
\text { WTO } \\
\text { necessary? }\end{array}$ \\
\hline $\begin{array}{l}\text { 1. Forced } \\
\text { technology } \\
\text { transfer }\end{array}$ & Yes & Yes & No & $\begin{array}{l}\text { No, but could } \\
\text { be useful }\end{array}$ & No \\
\hline $\begin{array}{l}\text { 2. Chinese } \\
\text { industrial } \\
\text { policies }\end{array}$ & $\begin{array}{l}\text { Depends on the } \\
\text { facts }\end{array}$ & $\begin{array}{l}\text { Yes, depending } \\
\text { on the facts }\end{array}$ & No & $\begin{array}{l}\text { No, but could } \\
\text { be useful }\end{array}$ & No \\
\hline $\begin{array}{l}\text { 3. Non-tariff } \\
\text { barriers and } \\
\text { high tariffs }\end{array}$ & $\begin{array}{l}\text { Yes, if } \\
\text { unjustifiable or } \\
\text { discriminatory }\end{array}$ & $\begin{array}{l}\text { Yes, if } \\
\text { unjustifiable or } \\
\text { discriminatory }\end{array}$ & No & Yes, for tariffs & No \\
\hline $\begin{array}{l}\text { 4. Agricultural } \\
\text { import bans }\end{array}$ & Yes & Yes & No & No & No \\
\hline $\begin{array}{l}\text { 5. Subsidies for } \\
\text { added industrial } \\
\text { capacity }\end{array}$ & $\begin{array}{l}\text { Yes, if no other } \\
\text { policy purpose }\end{array}$ & Yes & No & $\begin{array}{l}\text { No, but could } \\
\text { be useful }\end{array}$ & $\begin{array}{l}\text { No, but could } \\
\text { be useful }\end{array}$ \\
\hline $\begin{array}{l}\text { 6. Involuntary } \\
\text { licensing } \\
\text { requirements }\end{array}$ & Yes & Yes & Yes & $\begin{array}{l}\text { No, but could } \\
\text { be useful }\end{array}$ & No \\
\hline $\begin{array}{l}\text { 7. Disregard of } \\
\text { transparency } \\
\text { obligations }\end{array}$ & Yes & Yes & Yes & $\begin{array}{l}\text { No, but could } \\
\text { be useful }\end{array}$ & $\begin{array}{l}\text { No, but could } \\
\text { be useful }\end{array}$ \\
\hline $\begin{array}{l}\text { 8. Improper } \\
\text { trade remedies }\end{array}$ & Yes & Yes & No & Yes & No \\
\hline
\end{tabular}




\begin{tabular}{|c|c|c|c|c|c|}
\hline $\begin{array}{l}\text { 9. Data } \\
\text { localization }\end{array}$ & $\begin{array}{l}\text { Yes, depending } \\
\text { on the facts }\end{array}$ & $\begin{array}{l}\text { Yes, depending } \\
\text { on the facts }\end{array}$ & No & Yes & Yes \\
\hline $\begin{array}{l}\text { 10. China's } \\
\text { tariff retaliation }\end{array}$ & Yes & Yes & $\begin{array}{l}\text { Yes for } \\
\S 232 \\
\text { No for } \\
\S 301\end{array}$ & No & No \\
\hline $\begin{array}{l}\text { 11. Lack of } \\
\text { market-oriented } \\
\text { policies }\end{array}$ & No & $\begin{array}{l}\text { Maybe } \\
\text { depending on } \\
\text { future legal } \\
\text { interpretation }\end{array}$ & No & Yes & $\begin{array}{l}\text { Yes, in some } \\
\text { regimes }\end{array}$ \\
\hline $\begin{array}{l}\text { 12. High } \\
\text { bilateral trade } \\
\text { deficit }\end{array}$ & $\begin{array}{l}\text { No, but it is not } \\
\text { optimal }\end{array}$ & No & No & Yes & No \\
\hline $\begin{array}{l}13 . \\
\text { Unharmonized } \\
\text { tariffs and taxes }\end{array}$ & No & No & No & $\begin{array}{l}\text { No, not for } \\
\text { harmonization } \\
\text { in itself }\end{array}$ & No \\
\hline $\begin{array}{l}\text { 14. Belt and } \\
\text { Road }\end{array}$ & No & No & No & No & $\begin{array}{l}\text { Yes, in some } \\
\text { regimes }\end{array}$ \\
\hline $\begin{array}{l}15 . \\
\text { Unjustifiably } \\
\text { lax } \\
\text { environmental } \\
\text { standards }\end{array}$ & Yes & No & No & No & $\begin{array}{l}\text { Yes, in } \\
\text { environmental } \\
\text { regimes }\end{array}$ \\
\hline $\begin{array}{l}\text { 16. Securing } \\
\text { natural } \\
\text { resources }\end{array}$ & $\begin{array}{l}\text { Depends on the } \\
\text { facts }\end{array}$ & No & No & No & Yes \\
\hline $\begin{array}{l}\text { 17. Global } \\
\text { misallocation of } \\
\text { resources }\end{array}$ & Yes & No & No & No & $\begin{array}{l}\text { Yes, in the } \\
\text { climate regime }\end{array}$ \\
\hline
\end{tabular}




\begin{tabular}{|l|l|l|l|l|l|}
\hline $\begin{array}{l}\text { 18. China's } \\
\text { acquisitions in }\end{array}$ & Not in general & No & No & No & $\begin{array}{l}\text { This issue } \\
\text { amenable to } \\
\text { national law, } \\
\text { but more } \\
\text { international } \\
\text { cooperation } \\
\text { could be useful }\end{array}$ \\
\hline $\begin{array}{l}\text { 19. Corporate } \\
\text { governance law }\end{array}$ & No & No & No & No & No \\
\hline $\begin{array}{l}\text { 20. Cyber and } \\
\text { intellectual } \\
\text { property theft }\end{array}$ & Yes & Not generally & No & No & $\begin{array}{l}\text { This problem } \\
\text { amenable to } \\
\text { national law, } \\
\text { but more } \\
\text { international } \\
\text { cooperation } \\
\text { would be useful }\end{array}$ \\
\hline
\end{tabular}

\subsection{Overall Findings}

One of the most dangerous trade fallacies propounded by the Trump Administration is that its aggressive trade actions against China will "ensure that the costs of China's non-market economic system are borne by China, and not by the United States." ${ }^{147}$ Nothing can be further from reality. U.S. tariffs are paid by importers within the United States with the costs ultimately borne by either US domestic purchasers of imports or foreign exporters. A recent empirical study suggests that in this current episode, the costs are being borne by US consumers rather than Chinese exporters. ${ }^{148}$ While China may suffer some lost sales to the United States, the US economy definitely suffers harm. One analyst has recently predicted that "because China exports to Americans dwarf our exports to them, trade restrictions can inflict disproportionate harm to China's economy." 149 This argument errs by looking only at the export side of the trade transaction and not looking at the harm caused by US tariffs to Americans.

Besides being a double-edged weapon, US tariffs obscure the normative message that the United States should be communicating about China's misbehaviour. Instead, the US tariffs themselves become the message and China focuses its attention to how to defend itself from the assault by retaliating against the sender country and by shifting exports to third countries. In the US public arena, the processes to choose US tariff targets and award

${ }^{147}$ USTR, 2018 USTR Report to Congress on China's WTO compliance, February 2019, p. 25.

148 Fajgelbaum PD et al, The return to protectionism. 10 March 2019, http://www.econ.ucla.edu/pfajgelbaum/RTP.pdf

149 Porter R, Trump's big trade opening, Wall Street Journal, 14 March 2019. 
exemptions to lawyered-up importers absorb most of the media's attention. This cybernetic failure renders the tariffs an incoherent and defective strategy for transforming China.

As the Trump Administration will learn, the ad hoc nature of the Section 301 sanctions will make them difficult to remove in a negotiation with China. Because the sanctions are normless, a perfectionist-protectionist coalition is sure to rise up to fight against tariff removal. Both groups in the coalition will argue that the Administration should not be a patsy to empty promises by China.

The Trump Administration's most serious normative failure is to engage China through power rather than law. The narrative is oddly disjunctive. The Trump's Administrations anti-China rhetoric often sounds in law. For example, USTR explained that "Unfortunately, China has a poor record when it comes to complying with WTO rules and observing the fundamental principles on which the WTO agreements are based." ${ }^{150}$ The White House declared that Trump "is following through on his pledge to take action to ensure that China finally plays by the rules."151 Trump himself has referred to China's "illicit trade practices" and to its "misconduct." ${ }^{152}$ Given these assertions, the Administration's multiple failures to bring legal complaints is a non-sequitur.

The Administration has been remarkably candid as to why it has not invoked WTO dispute settlement:

China has no fear of WTO dispute settlement, even as it continues to embrace a state-led mercantilist approach to the economy and trade [...]. ${ }^{153}$

No matter how many cases are brought at the WTO, China can always find a way to engage in market-distorting practices. ${ }^{154}$

Any suggestion that the United States or other WTO members could address the numerous problems outlined in this [USTR] report solely by relying on the WTO dispute settlement mechanism is naïve in theory, and likely to prove downright harmful in practice. ${ }^{155}$

While the WTO dispute settlement process is of only limited value in dealing with China's non-market practices, the Chinese government is eager to draw upon the judicial activists at the WTO to protect its economic system. ${ }^{156}$

USTR provides no evidence to back up these claims and I am not aware of any. Whether or not China fears WTO dispute settlement, the government of China's failure to comply after losing a WTO case would seem to be no worse than the US government's failure to comply.

Instead, the Administration's true concern may be that continued compliance by China will put the spotlight on persistent non-compliance by the United States, especially on trade remedy violations. For the Trump Administration, WTO dispute settlement is a problem not a solution. That is why zeroing out the WTO Appellate Body is a higher priority for USTR

${ }^{150}$ USTR, 2018 USTR Report to Congress on China's WTO compliance, February 2019, p. 8.

${ }^{151}$ White House, What You Need to Know About President Donald J. Trump's Actions Responding to China's Unfair Trade Practices, 6 April 2018.

${ }^{152}$ White House, Statement from President Donald J. Trump on Additional Proposed Section 301 Remedies, 5 April 2018.

${ }^{153}$ USTR, 2019 Trade Policy Agenda and 2018 Annual Report, March 2019, p. 26.

${ }^{154}$ USTR, 2018 USTR Report to Congress on China's WTO compliance, February 2019, p. 10.

${ }^{155}$ USTR, 2018 USTR Report to Congress on China's WTO compliance, February 2019, p. 23.

${ }^{156}$ USTR, 2019 Trade Policy Agenda and 2018 Annual Report, March 2019, p. 26. 
than lodging cases against China. Moreover, if there will not be an Appellate Body after 2019, why bother bringing new legal cases against China?

By failing to make legal arguments against China, the Trump Administration dilutes whatever normativity may exist for persuading the world of its claim that China is not playing by the rules. Many WTO experts agree that the Administration has missed an opportunity to file WTO cases against China. ${ }^{157}$ In the current trade war against China, the most notorious rule-breaker is the United States which is ignoring its DSU Article 23 obligation to use the WTO dispute system rather than Section 301 and is ignoring its obligation not to impose unilateral tariffs on China.

The Trump Administration's myopia regarding the benefits of challenging China's actions as a violation of WTO rules is strangely shared others who are quick to point out what China is doing wrong. The most maddening advocacy comes from the U.S.-China Economic and Security Review Commission, an advisory group established by Congress in 2000. In its most recent report (the 2018 report which is its 16th annual report) the taxpayer-funded Commission floats the idea that USTR should bring a "non-violation" case against China at the WTO. ${ }^{158}$ Besides missing the key point that China is violating the WTO, a non-violation case is difficult to win and hardly worth the effort as any resulting award is unenforceable due to DSU Article 26.1.

In pointing out the obvious normative failures in the Trump Administration's strategy, I am certainly not suggesting that China always faithfully executes WTO law. Rather, my point is that the best way, and perhaps the only way, to get China to act more responsibly is to inculcate international legal norms into China's national trade practices. The Trump Administration's strategy to use coercion rather than reason to change China's behaviour may seem pragmatic and realist to Trump's team, but nothing could be more naive than to imagine that weapons that hurt the United States as much as (or more than) they hurt China will succeed in enabling the United States to dictate to China what China's economic policies will be.

As explained above, the US strategy of bilateral bargaining with China in the shadow of US tariffs suffers the pathology of displacing law with power. Another dimension of the pathology is the displacement of the multilateral WTO negotiating forum with secretive US-China bilateral talks. Other than No. 12 above, all of the US complaints about China reflect systemic issues that affect the WTO membership as a whole. Should China pledge to reduce state control, the ensuing policies can externalize benefits to all WTO members, not just the US. But there is also a danger of reaching exclusive US-China arrangements that would externalize costs on other WTO members. ${ }^{159}$

\section{Conclusion}

This study dissects America's top 20 charges against Chinese trade-related misbehaviour. The study finds that at least half of the charges (Nos. 1-10) violate WTO rules. Of those 10,

\footnotetext{
${ }^{157}$ For example, see Schoenbaum TJ, Chow DCK (2019), pp. 190-192.

${ }^{158}$ U.S.-China Economic and Security Review Commission, 2018 Report to Congress, November 2018 , p. 22.

${ }^{159}$ Bown CP, Why the US needs allies in a trade war against China, Harvard Business Review Digital, 11 December 2018, https://hbr.org/2018/12/why-the-u-s-needs-allies-in-a-trade-war-against-china
} 
the Trump Administration has brought claims against only three of them (Nos. 6, 7, and 10).

China should be held to the international rule of law, but so should the United States. The US tariffs being imposed against China under the Sections 201, 232, and 301 schemes violate international trade law, and this US misbehaviour in the WTO obscures misbehaviour by China. The US Section 301 tariffs have been imposed in response to five types of alleged misbehaviour by China (Nos. 1, 6, 10, 18, and 20). The Section 201 and 232 tariffs are not predicated on China's misbehaviour.

Table 1 above reveals notable surprising features of the US trade war against China: Six of the US claims are for types of behaviour that are not inherently wrongful in a diverse world economy and that are not a WTO violation (Nos. 11, 12, 13, 14, 18, and 19). Four types raise policy issues that are more properly considered outside of the WTO and for which better international cooperation is needed (Nos. 14-17.) Two of the types (Nos. 18, 20) relate to China's activities within the prescriptive jurisdiction of the United States for which the Trump Administration has tightened up domestic regulation and enforcement. Yet, the Trump Administration is also using Section 301 sanctions against those two types. The use of Section 301 sanctions for Chinese investment (No. 18) is especially perverse as China owes no duty to the US until US regulators prescribe what movements of capital and technology are prohibited.

Two of the claims (Nos. 12 and 18) ascribe to China's government full responsibility for actions that occur in large part in China's private sector. Seeking to make China's government accountable for private sector behaviour is consistent with the Trump Administration's assumptions as to the limited extent of market conditions in China. That logic is circular, however, because to achieve the changes that the Administration seeks in at least five claims (Nos. 1, 12, 17, 18, 19), the Chinese government will need to expand its control of private economic actors.

Seven of the US claims raise systemic issues for which WTO law is said to be inadequate to govern problems related to large non-market economies (Nos. 1, 2, 5, 7, 8, 9, 11). Yet the Trump Administration has not promoted WTO negotiations for any of these issues. Instead, the most USTR has done is to co-author a Joint Scoping Paper with the EU and Japan regarding the need for stronger rules on industrial subsidies, state-owned enterprises, the definition of a public body, and the identification of market-oriented conditions. ${ }^{160}$

If there are to be new international norms to govern the competition between market and non-market economies, the norms and standards have to be based on competitive neutrality principles that apply to all countries and economic systems equally. USTR can pontificate that China "continues to embrace a state-led mercantilist approach to the economy and trade that is fundamentally incompatible with the open, market-based approach envisioned and followed by other WTO members." 161 Nevertheless, to many observers, the Trump Administration's trade policies also look state-led, mercantilist, closed, and non-market based. This is especially true of the industrial policies for steel, aluminum, and washing machines, the calculated selection of beneficiaries of Section 301 tariffs, the blocking of

\footnotetext{
${ }^{160}$ See Joint Statement on Trilateral Meeting of the Trade Ministers of the United States, Japan, and the European Union, Annexed Statement 3, Joint Statement on Market Oriented Conditions, 31 May 2018.

${ }^{161}$ USTR, 2019 Trade Policy Agenda and 2018 Annual Report, March 2019, p. 26.
} 
China's inward investment into the United States, and Trump's recent expansion of BuyAmerican requirements. ${ }^{162}$

Decrying state capitalism is easy rhetorically, but when governments meet together to write rules, a granular approach is needed to unpack complex terms such as "state-led," "mercantilist," "open," and "market-based." How does an international regulator objectively determine when those indicated conditions exist? Are government policies to provide public goods state-led? Should steel "overcapacity" be addressed by market or non-market approaches? Will market-based policies be sufficient to address market failure? What strategies needed to control the pathologies of government failure? ${ }^{163}$ What rules should guide industrial policies in "open" economies? Should the SCM Agreement be expanded to cover implicit downstream subsidies? Anyone seeking to devise a code of fair competition between market and nonmarket economies will need to think through difficult questions such as these.

The existential challenge facing the OECD countries is not low-cost imports from China, but rather how to maintain an attractive development model for the rest of the world. The key advantage for the United States, Europe, and Japan is the jointly-shared embedded commitment to rule of law, democratic institutions, free markets, effective regulatory structures, and international cooperation.

The tragedy of the Trump Administration's economic aggression against China is its willingness to cast those principles aside in order to elicit ad hoc Chinese concessions. Whether or not the Chinese government agrees to alter some domestic policies, Trump's narcissistic economic war against China will erode the public's appreciation for the benefits of rule of law and international cooperation. By contrast, other than China's blunder in retaliating against the Section 301 tariffs, China has shown itself to be a WTO supporter that will not cave into US efforts to return the trading system to the law of the jungle. ${ }^{164}$ China was among the many governments that brought a WTO case against the Section 232 tariffs, and the recent WTO panel report in the Russia - Traffic in Transit case makes a win by the Section 232 plaintiffs much more likely. ${ }^{165}$

The Administration's efforts to shut down the Appellate Body may make it impossible for the United States to prosecute cases against China in the WTO dispute system. This is puzzling at a time when Trump himself is bragging that because of his policies, "we're doing better even with WTO. We're winning cases all of a sudden because they know my attitude." ${ }^{166}$ Of course, the US cannot win WTO cases against China unless USTR is willing to do the heavy lifting to prepare and prosecute such cases.

\footnotetext{
${ }^{162}$ Hoe S et al., Trump's new Executive Order requires additional Buy American preferences for infrastructure projects. Covington, 7 February 2019, https://www.insidegovernmentcontracts.com/2019/02/trumps-newexecutive-order-requires-additional-buy-american-preferences-infrastructure-projects/

${ }^{163}$ Charnovitz (2010).

${ }^{164}$ Deng C, China defends WTO record as trade fight looms. Wall Street Journal, 28 June 2018 (discussing China's White Paper). Taking note of China's pro-legalization stance, USTR has complained that "It is very troubling to see that China believes that giving more authority to the Appellate Body would be in China's interest." USTR, 2019 Trade Policy Agenda and 2018 Annual Report, March 2019, p. 27.

165 Baschuk B, WTO defies Trump with historic ruling on national security, 5 April 2019, https://www.bloomberg.com/news/articles/2019-04-05/wto-defies-trump-with-historic-first-ruling-onnational-security

${ }^{166}$ Trump claims U.S. winning more cases thanks to this trade policies, World Trade Online, 22 March 2019.
} 
By holding the Appellate Body hostage, the Trump Administration is apparently seeking to pressure other WTO members to agree to a change in DSU rules that would increase the likelihood of Appellate Body rulings against China as defendant and, at the same time, decrease the likelihood of rulings against the United States as defendant. Failing that firstbest outcome, the revealed preference of USTR seems to be to turn off WTO enforcement in order to preserve "policy space"167 for the US to impose WTO-illegal Section 301 and trade remedy tariffs against China. Rather than being viewed as a valuable public good, the judicial independence of the Appellate Body is despised by the Trump Administration as a restriction on US sovereignty. ${ }^{168}$

Although US unilateral power may still be strong enough to humble China, the projection of US power cannot be the sole basis on which to lead the world. Addressing the global problems of the 21 st century - particularly climate, health, and cyberspace - will require more intensive intergovernmental cooperation buttressed by an effective international legal system. ${ }^{169}$ The Trump Administration's rejection of global governance on trade, climate, and other important areas of law is a misstep of major consequence. Unlike the state of play when America rejected the League of Nations a century ago, this time there is a record of accomplishment by the multilateral system.

For its overall strategy to reform China and provide US global leadership on trade, I give the Trump Administration a generous grade of "D". The best features are the WTO cases lodged against Nos. 6, 7, and 10 and the exemplary case studies demonstrating how not to carry out trade policy. Three of Trump's complaints against China (Nos. 2, 3, and 8) expose the double standards in US protectionism. Five of the US complaints (Nos. 11, 14, 15, 16, 17) concern complex international problems for which the Administration has offered neither thoughtful ideas nor political leadership. The rest of Trump's trade strategy suffers for being poor lawyering (Nos. 1-11), mercantilist (No. 12), WTO-illegal (Nos. 1, 6, 10, 13, 18 , and 20), or nonsense (Nos. 13, 19).

${ }^{167}$ USTR, 2019 Trade Policy Agenda and 2018 Annual Report, March 2019, p. 27.

168 Patrick SM, Trump's search for absolute sovereignty could destroy the WTO, World Policy Review, 25 March 2019, https://www.cfr.org/blog/trumps-search-absolute-sovereignty-could-destroy-wto ${ }^{169}$ Haas (2019), p. 29. 


\section{References}

Aaronson S (2018) What are we talking about when we talk about digital protectionism?, World Trade Review online, 6 August 2018, https://www.cambridge.org/core/journals/world-trade-review/article/what-are-wetalking-about-when-we-talk-about-digitalprotectionism/F0C763191DE948D484C489798863E77B

Chaisse, J, Matsushita M (2018) China's 'Belt and Road' initiative: Mapping the world trade normative and strategic dimensions. Journal of World Trade 52(1):163-86

Charnovitz S (1993-94) Designing American industrial policy: General versus sectoral approaches. Stanford Law \& Policy Review 5:78-92

Charnovitz S (2001) The WTO and the rights of the individual. Intereconomics. Review of European Economic Policy 36(2): 98-108, https://archive.intereconomics.eu/year/2001/2/

Charnovitz S (2008), Mapping the law of WTO accession. In: Janow ME, Donaldson, V Yanovich, A (eds) The WTO: Governance, dispute settlement \& developing countries. Juris Publishing, Huntington, pp. 855-920

Charnovitz S (2010) Addressing government failure through international financial law. Journal of International Economic Law 13(3):743-761

Charnovitz S (2018) How American rejectionism undermines international economic law. Trade Law and Development 10(2):226-269

Ding Ru (2014) "Public Body" or not; Chinese state-owned enterprise. Journal of World Trade 48(1):167-190

Ehring L (2014) Nature and status of WTO accession commitments: "WTO-Plus" obligations and their relationship to other parts of the WTO Agreement. In: Cremona M, Hilpold P, Lavranos N, Schneider SS, Ziegler AR (eds) Reflections on the constitutionalisation of international economic law, Liber Amicorum for Ernst-Ulrich Petersmann, Martinus Nijhoff, Leiden, pp. 337-361

Esty DC (2019) (ed) The labyrinth of sustainability, Anthem Press. New York

Haas R (2019) How a world order ends. Foreign Affairs 98(1):22:30.

Meyer T (2018) Free trade, fair trade, and selective enforcement. Columbia Law Review $118(2): 491-566$

Petersmann, EU (2018) The 2018 trade wars as a threat to the world trading system and constitutional democracies. Trade Law and Development 10(2):179-225

Rovnov Y (2019) The life and death of a non-recurring subsidy: The role of change in ownership of subsidy recipient. Journal of World Trade 53(2):211-228

Schoenbaum TJ, Chow DCK (2019) The perils of economic nationalism and a proposed pathway to trade harmony. Stanford Law \& Policy Review 30:115-195 
Yamaoka T (2013) Analysis of China's accession commitments in the WTO: New taxonomy of more and less stringent commitments, and the struggle for mitigation by China. Journal of World Trade 47(1):105-158 